\title{
Developmental Defects of Enamel Tissue from Etiology to Minimally Invasive Treatment Procedures
}

\author{
Meric Berkman, (Corresponding author) \\ Department of Restorative Dentistry, Faculty of Dentistry, \\ Istanbul University, 34452, Fatih- Istanbul, Turkey \\ E-mail: meric.berkman@ogr.iu.edu.tr \\ Safa Tuncer \\ Department of Restorative Dentistry, Faculty of Dentistry, \\ Istanbul University, 34452, Fatih- Istanbul, Turkey \\ E-mail: safatuncer@gmail.com \\ Ferda Karabay \\ Department of Restorative Dentistry, Faculty of Dentistry, \\ Istanbul University, 34452, Fatih- Istanbul, Turkey \\ E-mail: ferdagecgel@hotmail.com \\ Mustafa Demirci \\ Department of Restorative Dentistry, Faculty of Dentistry, \\ Istanbul University, 34452, Fatih- Istanbul, Turkey \\ E-mail: md.demirci@gmail.com \\ Neslihan Tekce \\ Department of Restorative Dentistry, Faculty of Dentistry, \\ Kocaeli University, 41190, Basiskele- Kocaeli, Turkey \\ E-mail: neslihan_arslann@hotmail.com
}

\begin{abstract}
The development process of tissue and organs in the living body is managed by genetic components and is affected by systemic diseases or environmental factors such as trauma, chemicals and radiation. Depending on the development phase that these factors occur, conditions such as deviations from normal growth and development, and the disruptions of tissue quantity and quality may occur. Disruption of the normal functioning of the amelogenesis steps for various reasons causes defections of enamel matrix formation, resorption, and subsequent calcification process. Clinically, this situation appears as defects characterized by features ranging from diffuse opacities to the complete absence of tooth enamel. Developmental enamel defects, the prevalence of which varies between $10 \%$ and $80 \%$, cause problems that negatively affect individuals' quality of life, such as aesthetic problems, hypersensitivity, rapidly progressing caries, and tooth tissue loss. The aim of this study was to investigate the developmental enamel defects, their relationship with the development stages of the enamel, the etiological factors, in the light of current information. Clinical management of these defects and rehabilitation with minimally invasive approaches were evaluated with exemplary cases.
\end{abstract}

Keywords: Developmental enamel defects, amelogenesis, enamel hypoplasia, enamel hypomineralization, amelogenesis imperfecta.

DOI: $10.7176 / \mathrm{JSTR} / 6-09-07$ 


\title{
Etiyolojiden Minimal İnvaziv Tedavi Prosedürlerine Mine Dokusunun Gelişimsel Kusurları
}

\begin{abstract}
Özet
Canlı vücudundaki her doku ve organın gelişim süreci genetik unsurlar tarafindan yönetilmekte, sistemik hastalıklar veya travma, kimyasal maddeler, radyasyon gibi çevresel faktörlerden etkilenmektedir. $\mathrm{Bu}$ etkenlerin, meydana geldiği gelişim fazına bağlı olarak büyüme ve gelişimde normalden sapmalar, üretilen dokunun miktarı ve kalitesinde bozulma gibi durumlar ortaya çıkabilmektedir. Çeşitli nedenlerle amelogenez basamaklarının normal işleyişinin bozulması, mine matriksi oluşumu, rezorpsiyonu ve bunun devamındaki kalsifikasyon sürecinin sekteye uğramasına neden olmaktadır. $\mathrm{Bu}$ durum klinik olarak yaygın opasitelerden, diş minesinin tamamen yokluğuna kadar değişen özellikler ile karakterize olan kusurlar olarak karşımıza çıkmaktadır. Prevalansı \%10 ile $\% 80$ arasında değişen gelişimsel mine kusurları, estetik problemler, hassasiyet, ağrı, hızlı ilerleyen çürükler ve diş dokusu kayıpları gibi bireylerin yaşam kalitesini olumsuz etkileyen problemlere neden olmaktadır. Bu çalışmanın amacı, gelişimsel mine kusurlarııın, minenin gelişim safhaları ile olan ilişkisinin ve etiyolojik faktörlerinin güncel bilgiler ışığında incelenmesidir. Bu kusurların klinik yönetimi ve minimal invaziv yaklaşımlarla rehabilitasyonu, çalışmamızda örnek olgular eşliğinde değerlendirilmiştir.
\end{abstract}

Keywords: Gelişimsel mine kusurları, amelogenez, mine hipoplazisi, mine hipomineralizasyonu, amelogenezis imperfekta.

\section{Giriș}

Mine, ameloblast hücreleri tarafindan salgılanan, $\% 4$ oranında organik materyal ile su ve $\% 96$ oranında inorganik materyalden oluşan vücuttaki en sert dokudur. Organik yapıyı non-kollajen yapıdaki matriks proteinleri, inorganik yapıy ise mineral kristalleri meydana getirmektedir (Nanci, 2018; Smeets et al., 2019). 770 Newton'a kadarlık çiğneme kuvvetlerini kompanse edebilen ve ağız ortamında kesintisiz bir ısı-pH döngüsüne maruz kalan bu dokunun karakteristik mikro-yapısal birimi mine prizmasıdır ve hidroksiapatitten $\left(\mathrm{Ca}_{5}(\mathrm{PO} 4)_{3}(\mathrm{OH})_{2}\right)$ oluşan binlerce kristalden meydana gelmektedir. Olgun minedeki tipik bir mine kristali $10 \mu \mathrm{m}$ 'den büyük uzunluğa ve yaklaşık 50nm'lik genişliğe sahiptir (Smeets et al., 2019; Beniash et al., 2019). Apatit kristalleri mine prizmaları ile prizmalar arasındaki inter-prizmatik materyali oluşturan ve mine matürasyonu devam ettikçe kalınlaşıp genişleyen, hekzagonal formdaki uzun, şerit benzeri yapılardır. Mine prizmaları ise esasında düzenli prizmatik bir geometri sergilemeyen silindirik çubuk benzeri yapılardır. Her prizma bir inter-prizmatik materyal ile bitişiktir ve aralarındaki dar alanı sınırlandıran organik yapı prizma kılıfı olarak adlandırılmaktadır (Beniash et al., 2019; Nanci, 2018).

Doku ve organların gelişim süreci uterus tüpündeki yumurta hücresinin sperm hücresi ile döllenmesi itibariyle başlamaktadır. Totipotent bir zigot hücresinden bölünme, göç, programlanmış hücre ölümü, hücrelerin yeniden düzenlenmesi gibi organizasyonlarla organ sistemlerinin meydana geldiği bu süreçte hücrelerin gelecekteki konum, fonksiyon, şekilleri homeobox genleri ve büyüme faktörleri gibi mekanizmalar tarafindan belirlenip yönetilmektedir (Görmüş, 2011; Chiego, 2018; Moore et al., 2016). Diş gelişimi (odontogenez), nöral krestten köken alan mezenkim hücreleri (ektomezenkim) ile embriyonik oral ektoderm hücreleri (oral epitel) arasındaki karşılıklı etkileşim ile başlamaktadır. Oral epitelin diş gelişimi için planlanmış bölgelerinden transkripsiyon faktörleri (Pitx2, Foxi3, Dlx2, Lef1, p63) ve sinyal molekülleri (BMP, FGF, Wnt, SHH) salgılanması sonrasında altıncı haftanın başlarında oral epitelyumun kalınlaşması ile dental laminanın oluşması diş gelişiminin ilk belirtisidir. 10. haftada pre-odontoblastların odontoblastlara farklılaşması ile tip I kollajen bazlı bir organik matriks olan predentin sentezlenir ve salgılanır (dentiogenez). Odontoblastlar tarafindan üretilen BMP ve FGF moleküler sinyalleri yoluyla pre-ameloblastların ameloblastlara farklılaşması tetiklenir ve mine oluşumu (amelogenez) başlamış olur. Oluşan ameloblastların ürettiği Wnt, Runx ve TGF- $\beta$ sinyalleri odontoblastların farklılaşmasına neden olur. Hücreler farklılaştıkça ve hücre dışı matriks birikimi ilerledikçe, dentin-mine birleşimi oluşmaktadır. Mine gelişimi 300'den fazla genin kontrolü altında beş aşamada meydana gelmektedir (Moore et al., 2016; Kwon \& Jiang, 2018; Matalova et al., 2015; Chiego, 2018; Berke \& Keklikoğlu, 2010).

55 I P a g e

www.iiste.org 
1.1. Erken sekresyon safhası: Salgılama aşamasından önce predentinin üzerinde, tip IV kollajen ve laminin glikoproteini içerikli bazal membrana yaslanmış olan iç mine epiteli hücreleri, uzunluklarını artırıp pre-ameloblast hücrelerine dönüşür. Bazal membran dejenere olmaya başlar (Matalova et al., 2015; Chatzopoulos \& Tziafas, 2014).

1.2. Sekresyon safhası: Pre-ameloblast hücrelerinin çıkıntıları dejenere olan bazal membrandan, mineralize dentin yüzeyine uzanıp dentin kristallerinin üstünde ve çevresinde mine matriks proteinlerinin salgılanmasını başlatır. Dentin komşuluğunda oluşan bu ilk ince matriks (aprizmatik) mineralize olur ve mine-dentin birleşimi meydana gelmeye başlar. Diğer bir yandan ameloblast hücreleri laminin, klaudin ve integrin izoformları salgılar ve birbirine sıkı bağlı olan bir hücre tabakası (ameloblast salgı membranı) ve hücreler arasındaki iyon ve çözelti geçişini sağlayan mineralizasyon yüzü'nü oluşturmak üzere organize olurlar. Ameloblastlar, eskiden bazal membranın bulunduğu boşluğa doğru, özelleşmiş Tomes uzantıları oluşturur ve mine kristallerinin uzunluğunun arttı̆̆ 1 mineralizasyon yüzünde protein salgılanması devam eder. Zamanla Tomes uzantıları kaybolur ve her mine prizması ameloblasttan geri çekilen Tomes uzantısını takip eder. Sekresyon fazının sonunda mine matriksi belirlenen kalınlığa ulaştığında, ameloblastlar aprizmatik son mine tabakasını oluşturarak Tomes uzantılarını tamamen kaybeder. Ameloblastlar tarafindan salgilanan amelogenin, ameloblastin, enamelin, tuftelin gibi önemli mine matriks proteinleri (Tablo-1), organik matriks depozisyonunu gerçekleştirirken, matriksin içine doğru salgılanan enamelisin (MMP-20) proteinazı ise organik matriksin enzimatik işlenme sürecini başlatır ve erken olgunlaşma döneminde de salgılanmaya devam eder. Bu degradasyon işlemi sonucu üretilen daha küçük peptitlerin bir kısmı mineralizasyon sinyali olarak işlev görürken diğer bir kısmı başlangıç kristal oluşumunu koordine etmek üzere birleşip nanosferik yapılar oluşturur. Mine mineralizasyonunun yaklaşık \%30'unun sekresyon aşamasında gerçekleştiği belirtilmektedir. Mine bu aşamada yumuşak ve mat beyazdır (Matalova et al., 2015; Chatzopoulos \& Tziafas, 2014; Yamaguti \& Cabral, 2019; Neville et al., 2015; Hu et al., 2007).

Tablo 1. Mine gelişiminde görevli başlıca proteinler (Matalova et al., 2015; Yamaguti \& Cabral, 2019; Neville et al., 2015; Hu et al., 2007; Seow, 2014; Deutsch et al., 1994)

\begin{tabular}{|c|c|c|c|}
\hline Protein & $\begin{array}{l}\text { Kodlayan } \\
\text { Gen }\end{array}$ & Fonksiyonu & Hasarında Oluşan Kusur \\
\hline Amelogenin & AMELX & $\begin{array}{l}\text { Organik mine matriksinin } \\
\% 90 \text { 'mının oluşturur. Mine } \\
\text { kristallerinin şekil ve boyutunu } \\
\text { düzenler. }\end{array}$ & $\begin{array}{l}\text { Yüzeyde çukurcuk, ince } \\
\text { kalınlıkta mine, hipoplazi, X- } \\
\text { e bağlı hipoplastik } \\
\text { amelogenesis imperfekta, X- } \\
\text { e bağlı hipomatür } \\
\text { amelogenesis imperfekta }\end{array}$ \\
\hline Ameloblastin & AMBN & $\begin{array}{l}\text { Mine matriksinin \%5ini oluşturur, } \\
\text { hidroksiapatit kristallerinin } \\
\text { depozisyonu ve mine } \\
\text { prizmalarının oluşmasında } \\
\text { görevlidir. Prizma ile } \\
\text { interprizmatik materyal arası } \\
\text { kllıfta birikerek prizma sınırını } \\
\text { korur. }\end{array}$ & $\begin{array}{l}\text { Yüzeyde çukurcuk, } \\
\text { hipoplazik mine }\end{array}$ \\
\hline Enamelin & ENAM & $\begin{array}{l}\text { Mine matriksinin } \% 1-\% 5 \text { 'ini } \\
\text { oluşturan en büyük mine } \\
\text { proteinidir. Amelogenin ile } \\
\text { birlikte, hidroksiapatit } \\
\text { kristallerinin depozisyonunu } \\
\text { sağlar. Diğer mine proteinleriyle } \\
\text { etkileşime geçip mine } \\
\text { prizmalarının boylarını düzenler. }\end{array}$ & $\begin{array}{l}\text { Yüzeyde çukurcuk, ince } \\
\text { kalınlıkta mine, otozomal } \\
\text { dominant hipoplastik } \\
\text { amelogenesis imperfekta }\end{array}$ \\
\hline Enamelisin & MMP-20 & $\begin{array}{l}\text { Amelogenin parçalanmasında ve } \\
\text { matriks proteinlerinin } \\
\text { işlenmesinde rol oynayan ana } \\
\text { proteinazdır. }\end{array}$ & $\begin{array}{l}\text { Normal kalınlıkta yumuşak } \\
\text { mine, hipomatürasyon, } \\
\text { hipomineralizasyon, } \\
\text { otozomal resesif hipomatür } \\
\text { amelogenesis imperfekta }\end{array}$ \\
\hline
\end{tabular}




\begin{tabular}{|llll|}
\hline Kallikrein-4 & KLK4 & $\begin{array}{l}\text { Olgunlaşma fazında salgılanır. } \\
\text { Enamelisinin parçalayamadığ1 } \\
\text { proteinlerin parçalanmasından } \\
\text { sorumlu olan agresif bir } \\
\text { proteinazdır. }\end{array}$ & $\begin{array}{l}\text { Normal kalınlıta yumuşak } \\
\text { mine, hipomatürasyon, } \\
\text { hipomineralizasyon, } \\
\text { otozomal resesif hipomatür } \\
\text { amelogenesis imperfekta }\end{array}$ \\
\hline & $\begin{array}{l}\text { Enamelin protein ailesine aittir. } \\
\text { Mine tuğlarında bulunan } \\
\text { morfolojik bir mine elementidir. } \\
\text { Minenin mineralizasyon ve } \\
\text { Tuftelin }\end{array}$ & $\begin{array}{l}\text { Hipoplastik tip amelogenesis } \\
\text { alır. }\end{array}$ & $\begin{array}{l}\text { imperfekta ile ilişkili } \\
\text { bulunmuştur. }\end{array}$ \\
& TUFT1 & & \\
& &
\end{tabular}

1.3. Geçiş safhası: Belirlenen mine kalınlığı miktarına ulaşıldığında, hücreler yapısal ve işlevsel değişimler geçirmeye başlar. 60-70 $\mu \mathrm{m}$ uzunlukta olan ameloblastlar büzülür ve $40 \mu \mathrm{m}$ uzunluğa gelir. Ameloblast hücrelerinin protein salgılama aktivitesi azalır ve üretilen protein cinsleri değişir (Chatzopoulos \& Tziafas, 2014; Neville et al., 2015).

1.4. Olgunlaşma (Matürasyon) safhası: Erken olgunlaşma döneminde Kallikrein-4 proteazının salgılanmaya başlaması ve enamelisin salgılanmasının devam etmesi ile organik matriksin degradasyonu ve ortamdan uzaklaştırılması sağlanır. Bu durum mine kristalitlerinin uzunluğunun artışını sonlandırır, ince kristallerin etrafında mineral depozisyonu gerçekleşerek kristaller birbirlerine değene kadar genişlik ve kalınlıktaki büyümeleri hızlanır. Ameloblastların yaklaşık \%50'sinde apoptoz görülür, geri kalan hücreler boyutlarını küçültür ve diş sürene kadar mineyi koruyan bir hücre tabakası oluşturur. Protein ve suyun kaybı ile \%96 oranında mineral içeren son derece sert yapıdaki translusent mine oluşur. Florürün de kristal yapıya dahil olduğu bu olgunlaşma fazı daimî insan dişinde 3-6 yıl boyunca devam eder (Matalova et al., 2015; Chatzopoulos \& Tziafas, 2014; Yamaguti \& Cabral, 2019; Neville et al., 2015; Hu et al., 2007).

1.5. Geç olgunlaşma safhası: Mine organı fonksiyonunu durdurur ve dejenere olmaya başlar. Mine epiteli yıkılır (Chatzopoulos \& Tziafas, 2014).

Gelişen minenin fenotipi, spesifik genetik mutasyonlardan veya çevresel değişkenlerden etkilenmektedir. Genetik faktörlerin etkisi kalıcı olduğu için dişin gelişiminin başından bitimine kadarki tüm süreçler etkilenmekteyken, çevresel faktörlerle oluşan kusurlar, etkenin denk geldiği gelişim safhasına bağlı olarak oluşmaktadır (Nowak et al., 2019).

\section{Gelişimsel Mine Kusurlarının Klinik Sınıflaması}

Gelişimsel mine kusurlarının etiyolojiden bağımsız olan sınıflandırması, mine dokusunun klinik görünümüne göre yapılmaktadır.

2.1. Hipoplazi: Sekresyon aşamasında matriks üretiminde oluşan aksaklıklar nedeniyle, üretilen doku miktarının normalden az olduğu, kantitatif bir gelişimsel kusurdur. Minenin sertliği normal ancak kalınlığı normalden azdır, şiddetli olgularda hiç oluşmayabilir. Klinik görünüm ince, çukurcuklu veya oluklu mine veya yer yer minenin oluşmaması ile karakterizedir (Resim-1) (Seow, 2014; Schuurs, 2013).

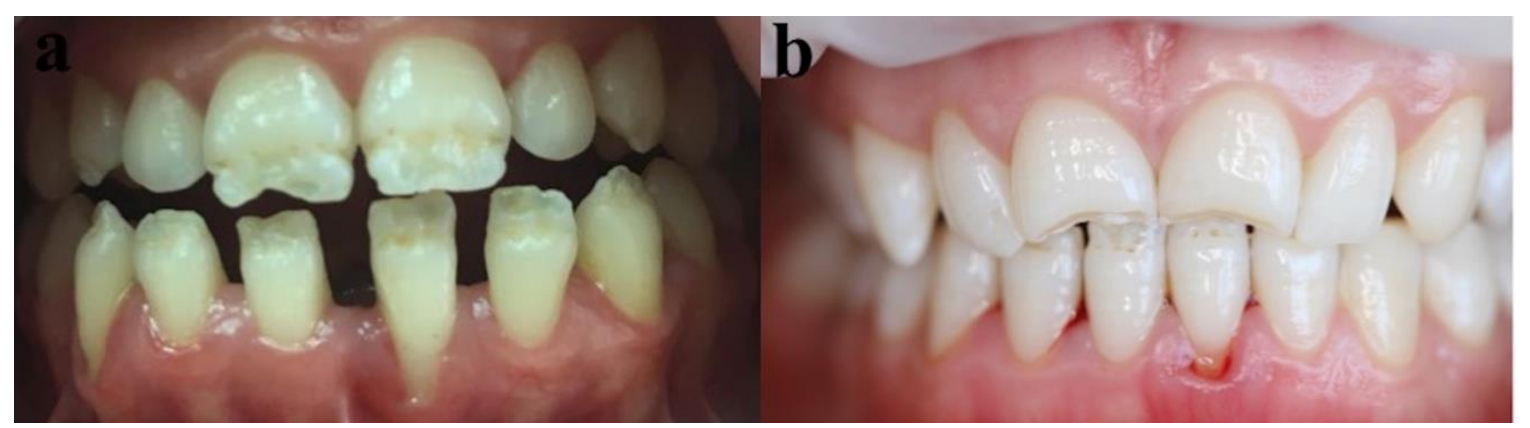

Resim 1. a, b: Mine hipoplazisi lezyonlarının klinik görünümü. 


\subsection{Hipokalsifikasyon:}

2.2.1 Hipomineralizasyon: Mineralizasyon aşamasında organik mine matriksinin rezorpsiyonundaki ve aktif kalsiyum taşınmasındaki aksaklıklar nedeniyle oluşan kalitatif bir gelişimsel eksikliktir. Minenin kalınlığı normaldir ancak normalden daha yumuşak ve zayıftır. Klinik olarak translusensi özelliği etkilenmiştir, sınırlı veya difüz olan tebeşirimsi, beyaz, sarı veya kahverengi opasiteler olarak gözlemlenir. Difüz opasitelerin derinliği genelde $150 \mu \mathrm{m}$ 'dan azdır. Renkli opasiteler beyazdan, beyaz opasiteler de normal mineden daha yumuşaktır (Resim-2) (Seow, 2014; Schuurs, 2013).

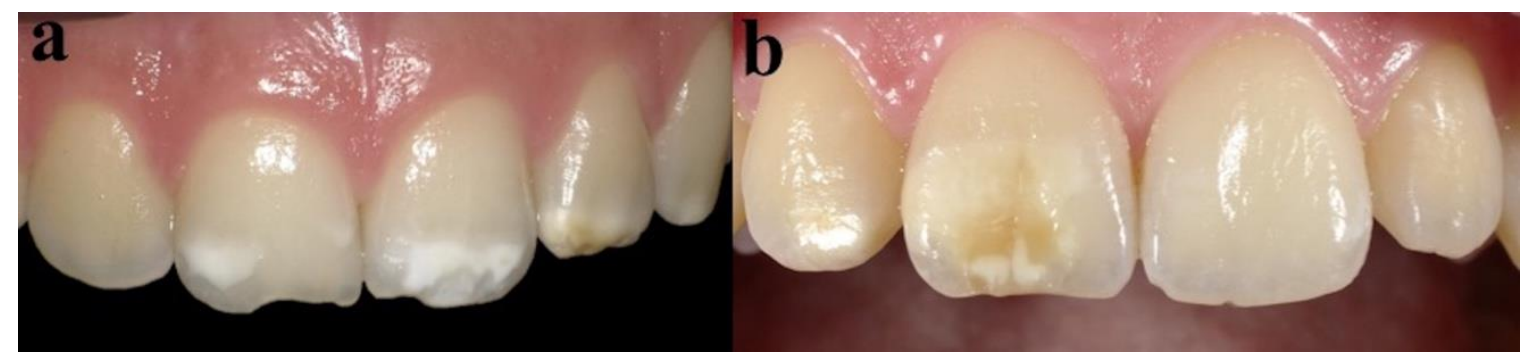

Resim 2. a, b: Mine hipomineralizasyonu lezyonlarının klinik görünümü.

2.2.2 Hipomatürasyon: Olgunlaşma aşamasında ortamda kalan organik matriksin tamamen uzaklaşamaması nedeniyle mineral depozisyonunun yetersiz olmasıdır. Mine normal kalınlıkta ancak yumuşak ve kırılgandır. Klinik olarak translusensi özelliğinin etkilendiği ve yüzeyinin tamamında veya belli bir bölgesinde oluşan opasiteler ile karakterizedir (Resim-3) (Seow, 2014).

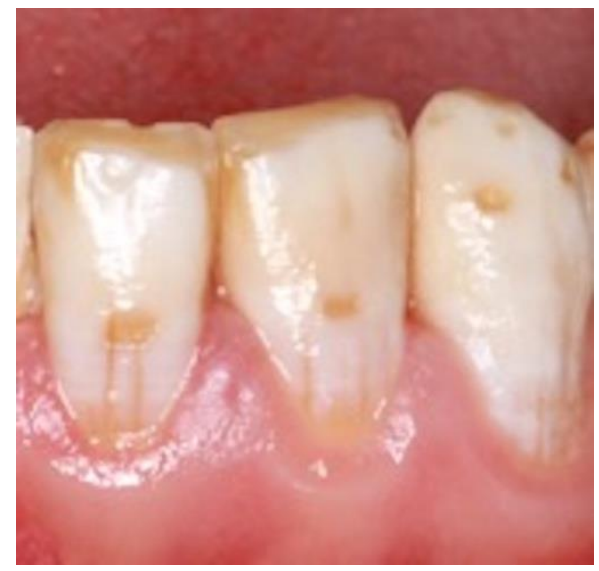

Resim 3: Mine hipomatürasyonu lezyonlarının klinik görünümü.

2.3. Lokalize hipoplazi/hipokalsifikasyon: Tek bir diş veya birkaç dişin etkilendiği küçük kusurlardır. Kusurların büyüklüğü, diş dizisindeki ve kurondaki lokalizasyonu, faktörün şiddeti ve bu faktöre maruz kalma zamanına göre değişir. Travma, enfeksiyon gibi lokal etkenler nedeniyle meydana gelmektedir (Ansari et al., 2018).

2.4. Generalize hipoplazi/hipokalsifikasyon: Diş dizisindeki tüm dişlerin yüzeylerinin bir kısmı veya tamamı etkilenmektedir. Sistemik veya genetik faktörler nedeniyle meydana gelir. Yaygın renk değişikliği, amelogenesis imperfekta, florozis bu tip mine defektlerini içermektedir (Ansari et al., 2018).

\section{Etiyolojik Faktörler ve Gelişimsel Mine Kusurları}

Mine gelişimini etkileyen faktörler meydana geldiği zamana bağlı olarak pre, peri veya post-natal olmak üzere lokal ile sistemik çevresel faktörler ve genetik faktörler olarak sınıflandırılabilir. Mine yapısı gelişim sonrasında değişmediğinden minedeki kusurun lokalizasyonu etkinin meydana geldiği 
zamanın yaklaşık olarak tespit edilmesine yardımcı olur. Çevresel ve genetik sistemik faktörlerin fenotipi simetrik olarak ortaya çıkmakta iken travma gibi lokal faktörler yalnızca meydana geldiği lokalizasyondaki dişi etkilemektedir. Her iki diş dizisi de kusurlu ise sebebi yüksek ihtimalde genetik nedenlidir (Seow, 2014; Schuurs, 2013).

\section{1. Çevresel Faktörlerin Neden Olduğu Gelişimsel Bozukluklar}

Gelişmekte olan diş germindeki ameloblastlar dış uyaranlara karşı son derece duyarlıdır ve birçok faktör minede anormalliklere neden olabilmektedir.

Enfeksiyon hastalıkları ve yüksek ateş: Annenin hamileliği esnasında veya bebeğin doğum ile 3 yaş arasında geçirdiği sitomegalovirüs, konjenital sifiliz (Hutchinson keserleri, dut molarları), ekzantemöz hastalıklar (Kızamık, kızamıkçık, su çiçeği gibi viral, kızıl gibi bakteriyel çocukluk çağı hastalıkları), ekzantemöz olmayan bulaşıcı hastalıkların (Boğmaca, tüberküloz, pnemoni, idrar yolu enfeksiyonu, orta kulak iltihabı) mikroorganizmalar aracılığıyla ameloblastları direkt etkileyerek veya uzun süreli yüksek ateş ile hücresel fonksiyonunu bozup indirekt olarak etkilemesi nedeniyle minede hipomineralizasyon veya hipoplazi kusurları meydana gelmektedir. Diğer yandan uzun süreli yüksek ateş dehidratasyona ve bunun neticesinde böbrek fonksiyonlarında bozulmaya, serumdaki kalsiyumfosfat oranının değişmesine neden olmaktadır. Serumdaki düşük kalsiyum seviyesi hipoplastik mineye, fosfat eksikliği ise büyük miktarda interglobüler dentin varlığına neden olmaktadır. Kısa süreli yüksek ateşin ameloblastları etkilemeyeceği, bunun da neden enfeksiyon geçicen her çocukta mine defekti olmayacağını açıkladığı belirtilmektedir. (Neville et al., 2015; Seow, 2014; Schuurs, 2013).

Turner hipoplazisi: Süt dişlerinin apikal abselerindeki mikroorganizmalar, kökler altında gelişmekte olan germlerdeki amelogenezi etkileyerek kusurlara neden olmaktadır. Enfeksiyonun meydana gelme zamanı, şiddeti ve daimî dişin konumu oluşan lezyonun derecesini ve lokalizasyonunu belirler. Kusurlar beyaz, sarı, kahverengi renkleşmelerden tüm kuronu kaplayan hipoplazilere kadar çeşitlilik göstermektedir. Küçük azı dişleri bu durumdan kesici dişlere göre iki kat daha fazla etkilenmektedirler çünkü genellikle süt ön kesicilerde apikal inflamatuvar bir hastalık oluşana kadar alttaki daimî dişin kuronu tamamlanmış olur (Neville et al., 2015; Schuurs, 2013).

Lokal, akut, mekanik travma: Düşme, cerrahi operasyon, trafik kazası gibi nedenlerle mine organının etkilenmesi, hipomineralizasyondan hipoplaziye kadar değişen mine kusurlarına, mavi- griden, sarıyeşile değişen renk değişimlerine yol açmaktadır (Neville et al., 2015).

Orotrakeal entübasyon: Özellikle prematür bebeklerde oksijen ihtiyacı için orotrakeal tüp uygulanması ile alveolar kemiğin sıkışması nedeniyle kesici dişlerde opak veya sarı-kahverengi mine hipoplazileri görüldüğü belirtilmektetir. Özellikle sağ taraftaki kesiciler tüpün sabitlenmesi nedeniyle, sol taraf ise laringoskopi nedeniyle hasar görmektedir (Seow, 2014; Schuurs, 2013).

Prematür doğum: Düşük doğum ağırlıklı bebeklerde mine hipoplazisi riski yüksektir. Bu kusurlar genellikle erken doğumla ilişkili orotrakeal entübasyon, solunum yetmezliği, kardiyovasküler, renal anormaliler, anemi, hipoksi gibi olumsuz sistemik durumlardan kaynaklanmaktadır (Neville et al., 2015; Schuurs, 2013).

Malnutrasyon: Karaciğerde depolanan A vitamini embriyogenez, büyüme ve epitel farklılaşması için gereklidir. Şiddetli A vitamini eksikliği durumunda predentin ve organik mine matrixi yapımı aksar. Hipervitaminoz A durumunda ise toksik etkiler diş germinin gelişimini etkiler. $\mathrm{C}$ vitamini kollajen sentezi ve lizin ile prolin moleküllerinin düzenlenmesi için gereklidir, eksikliği odontegenezin aksamasına, minede çukurcuk şeklinde kusurların oluşmasına neden olmaktadır (Schuurs, 2013). D vitamini paratiroid hormon ile birlikte serumdaki kalsiyum-fosfat seviyelerini dengeler. Diyetle alınan (ergokalsiferol, D2) veya endojen olarak ultraviyole işınlarla deride üretilen (kolekalsiferol, D3) D vitamininin aktif formu olan 1,25-dihidroksivitamin $\mathrm{D}[1,25(\mathrm{OH}) 2 \mathrm{D}]$, bu minerallerin ince bağırsaktan emilimini sağlayıp ve böbreklerden kaybını engelleyerek kandaki seviyelerini düzenlemekte ve odontogenezin aksamasını önlemektedir (Turgut et al., 2018; Hatun et al., 2003). Hipovitaminoz D ile oluşan raşitizmde iskelet tamamen kemikleşmez, osteoid dokular hipertorfiktir. Normal yükler altında kemik şekli bozulur, bacaklar yana eğrilir. Şiddetli raşitizm vakalarında minede hipoplazi görülmektedir ve pulpa odası oldukça geniştir. Konjenital hipotiroidizmi olan çocukların yarısında hem doğum öncesi hem de doğum sonrası oluşan mine hipomineralize ve hipoplastiktir. Minedeki porözitelerin boyutu, özellikle doğumdan önce tiroksin eksikliği başladığında artar. Paratiroid hormonun etkisi amelogenezin salgılama aşamasında, mine organı tarafından alınan kalsiyum miktarı açısından önemlidir. Hipoparatiroidizmde mine, hormon eksikliğinin ektodermal etkileri nedeniyle veya düşük kalsiyum seviyesinin doğrudan bir sonucu olarak hipoplastiktir (Schuurs, 2013).

Nörolojik hastalıklar: Ensefalopati, serebral palsi, santral paraliz gibi durumlara neden olan doğum öncesi veya esnasında geçirilen asfiksi, yüksek ateş gibi etkenlerin hem beyin hücrelerini hem de mine

59 | P a g e

www.iiste.org 
gelişimini etkileyip mine hipoplazisine neden olduğu belirtilmektedir (Neville et al., 2015; Schuurs, 2013).

Antineoplastik terapi: Özellikle 5 yaş öncesindeki radyoterapi uygulamalarının 10Gy'de ameloblastların hasar görmesine, 20-40Gy'yi aşan dozlarda ise mikrodonti, hipodonti, radiküler hipoplazi ve minede hipokalsifikasyon veya hipoplazilere neden olduğu belirtilmektedir (Kaste et al., 1994; Kaste et al., 2009). Kemoterapi alan lösemili çocuklarda tüm dişlerin kronlarında beyaz-krem veya sar1-kahverengi opasiteler gözlenmiştir (Schuurs, 2013). Orbitasında rabdomyosarkom olan 7 yaşındaki hastanın alt ve üst çenesine sırasıyla 5Gy'den ve 10 Gy'den daha az ortalamalarda radyasyon dozu verilmiş olan bir çalışmada hastada belirgin dentofasiyal anormallikler gelişmediği belirtilmiştir (Owosho et al., 2016).

Kimyasal ajanlar (Sigara, tetrasiklin, dioksin): Klamidya enfeksiyonu, romatoid artrit, kistik fibroz gibi hastalıklarda kullanılan tetrasiklin grubu antibiyotiklerden özellikle minosiklinin uzun süreli kullanımı, kemik, diş, tırnak gibi dokularda, ilacın aromatik halkasının bozulması esnasında çözünemeyen kinon pigmentinin birikimi sonucu sarı, kahverengi, gri renkleşmelere neden olmaktadır. Sarı renkleşme meydana gelen doku gün ışığına maruz kaldıkça oksidasyon ile kahverengi-griye döner. Tetrasiklinler plasenta yolu ile fetusa, anne sütü yolu ile bebeğe geçer bu nedenle hem süt hem daimî dişlerde ameloblastlar etkilenir, minede bant şeklinde hipoplazi, dentinde kahverengiden mavi-griye kadar değişen renkleşmeye neden olurlar. Zamanla dişlerin ortam ışı̆̆ına maruz kalan ön dişlerin bukkal kısımları koyulaşır lingual yüzeyler ve arka dişler sarı kalır. Bu ilacın 8 yaşından önce reçete edilmemesi gerekmektedir (Nanci, 2018; Neville et al., 2015; Seow, 2014; Schuurs, 2013).

Eritroblastosis fetalis ve AB0 kan grubu uyuşmazlığı: Kan grubu Rh- olan anne ile Rh+ olan babadan meydana gelen bebek, baba eğer heterozigot değilse \%50 ihtimalle Rh+ kan grubuna sahip olmaktadır. Gebelik ve doğum esnasında fetustaki eritrositler (antijenler) annenin dolaşımına geçtiğinde annede antikor yapımı olur ve bu antikorlar bebeğe geçtiğinde hemoliz başlar, konjenital hemolitik anemi meydana gelir (Bağbozan, 1995). Eritrositlerin yıkımı ile oluşan aşırı bilirubin miktarı dokularda birikir, sarılığa, beyinde bazal ganglionda hasara ve dentinde renkleşmeye neden olur. Bu bebeklerde $0.1 \%-30 \%$ oranında minede hipoplazi görülmektedir. $\mathrm{Bu}$ hipoplazi konjuge olmayan billirubin miktarının ameloblasta verdiği hasar miktarına bağlı olarak değişir (Schuurs, 2013).

Hiperbilirubinemi: Eritroblastosis fetalis veya biliyer atrezi nedeniyle kandaki bilirubin seviyesinin artması, dokularda bilirubin yıkım ürünü olan biliverdin birikimine (sarılık) neden olmaktadır. Hiperbilirubinemide dişler sarı-yeşil renktedir (kolorodontia) ve minede hipoplazi görülmektedir (Chatzopoulos \& Tziafas, 2014; Seow, 2014; Schuurs, 2013).

Florozis (Endemik Dental Floroz, Colorado Brown Stain, Mottled Enamel): Amelogenez esnasında yüksek konsantrasyonda (florür konsantrasyonu 1-2ppmi aşan içme suları) kronik florür alımının ameloblast aktivitesini etkilemesi, simetrik dişlerde beyaz veya kahverengi opasiteler ile karakterize mine kusurları meydana getirmektedir. İnsan sağlığı için hayati önem taşıyan florür su, yiyecekler ve hava yoluyla alınmaktadır. İnsan vücuduna alınan florun yiyeceklerdeki konsantrasyonu düşük olduğundan asıl florür kaynağı sudur ve su kaynaklarındaki optimal florür konsantrasyonları iklime ve su tüketim miktarına göre değişiklik göstermektedir (Dedekayaoğulları \& Önal, 2009). Örneğin tropikal iklim bölgelerindeki su içme ihtiyacı, 1lıman iklim bölgelerindeki su içme ihtiyacına göre daha fazladır, bu nedenle florür konsantrasyonu daha az olmak zorundadır. Her ne kadar günlük alınabilecek optimal florür konsantrasyonları kontrol altına alınmış olsa da sistemik veya topikal florür preparatlarının aşırı kullanımı gibi durumlar da florozise neden olabilmektedir (Nanci, 2018; Neville et al., 2015; Schuurs, 2013).

Yüksek konsatrasyondaki florür, Bcl-2 gibi antiapoptoz proteinlerinin baskılanmasına neden olur. Bu durum ameloblastların programlanmış hücre apoptozunu tetikler, MMP-20 gibi proteaz enzimlerinin sentez ve sekresyonunu engeller (Schoppmeier et al., 2018). Mine matrix proteinlerinin başarısız degradasyonu nedeniyle apatit kristallerinin büyümesi ve mineral difüzyonunun önlenmesi söz konusudur ve sağlam mine yüzeyinin altında oluşan bu hipomineralize alanda içerisinde su ve hava olan mikroporoziteler bulunmaktadır. $\mathrm{Bu}$ durum refrakrif indeksi ve internal 1 şı yansımasını değiştirerek opasiteyi artırmaktadır (Paris \& Meyer-Lueckel, 2009).

Florotik minenin sertliği etkilenmemiş mineden daha azdır. Hafif floroziste, kesici kenara paralel uzanan, ince bant ya da benek şeklinde beyaz-opak çizgilenmeler söz konusudur. Orta şiddetli floroziste sarı-kahverengi lekelenmeler, daha şiddetli florozis olgularında ise tebeşirimsi-opak lezyonlar, diyet alışkanlıklarına göre koyu kahverengi renkleşmeler, poröz yüzeyler ve sürme sonrası oluşan çukurcuklu alanlar görülmektedir (Schoppmeier et al., 2018). Florozis opasiteleri dişler sürdüğünde mevcuttur ancak renkleşmelerin sürme sonrası alınan diyet pigmentlerine bağlı oluştuğu belirtilmektedir (Barzotto \& Rigo, 2018). Çalışmalarda, bireylerin genetik yapısına bağlı olarak diş florozuna karşı olan risk ve dirençlerinin farklı olduğu savunulmaktadır (Schuurs, 2013).

$60 \mid \mathrm{P}$ a g e

www.iiste.org 
Büyük Azı-Kesici Diş Hipomineralizasyonu (BAKH): Ufak renk değişimlerinden tüm kuronu kaplayan, geniş beyaz-opak veya sarı-kahverengi, iyi sınırlı, asimetrik kusurlara kadar çeşitlilik gösteren bu hastalık, esasında 1970'li yıllardan beri bilinmektedir ve peynir molarları (Holland cheese molars), minenin idiyopatik hipomineralizasyonu gibi farklı terimlerle isimlendirilmiştir. Molar-kesici hipomineralizasyonu adlandırması, 2000 yılında Avrupa Pediatrik Dişhekimliği Birliği (EAPD) tarafindan belirlenmiş olup, 2001 yılında Weerhejm ve arkadaşları tarafından; en az bir daimî moların etkilendiği ve kesici dişlerin de dahil olabildiği sınırlı ve niteliksel gelişimsel mine defekti olarak tanımlanmıştır (Nowak et al., 2019, Weerheijm et al., 2001).

Etkilenmiş dişler hipoplastik değildir, normal kalınlıkta ancak yumuşak, kırılgan ve porözdür (Resim4). Olgunlaşma fazında ameloblast fonksiyonunun bozulması nedeniyle yetersiz mineralizasyon ve minenin normalden fazla protein ile su içermesine bağlı olarak oluşmaktadır (niteliksel hasar). Dişler fonksiyona geldikten kısa bir süre sonra, çiğneme kuvvetleri ile aşınmakta, kırık veya çürüklere bağlı olarak hızlı bir yıkıma uğramaktadır. Bu durum klinik görünümünün hipoplazi ile karıştırılmasına neden olmaktadır. Sar1-kahverengi kusurlar, krem-beyaz kusurlara göre daha porözdür ve aşınma ve kırığa daha eğilimlidirler. Diş yapısının zayıf olması ve aşırı hassasiyet nedeniyle oral hijyenin sağlanamaması hızlı ilerleyen çürüklere yol açmakta, pulpa enflamasyonu nedeniyle klinikte lokal anestezinin sağlanması güçleşmektir (Yamaguti \& Cabral, 2019; Neville et al., 2015; Nowak et al., 2019; Elhennawy et al., 2017).

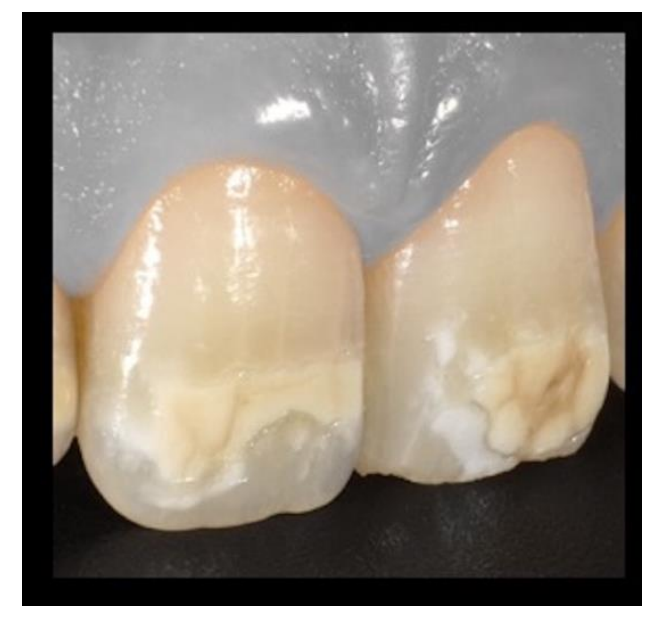

Resim 4: Büyük Azı-Kesici Diş Hipomineralizasyonu lezyonlarının klinik görünümü.

Minenin kalsiyum ve fosfat seviyeleri normale göre ortalama \%28 oranında azalmış, karbon, magnezyum, potasyum konsantrasyonu ve protein içeriği (normal minenin 3-21 katı) artmıştır (Elhennawy et al., 2017; Ekambaram \& Yiu, 2016).

$\mathrm{Bu}$ nedenle sertlik ve elastik modülüs normalden düşüktür. Mine kristalleri normal mineye göre daha az yoğunlukta dizilmiş, inter-prizmatik kılıf daha kalın, inter-prizmatik protein içeriği daha fazladır. BAKH'lı minelerde albümin, alfa-1-antitripsin, antitrombin III, Tip I kollajen gibi proteinler tespit edilmiştir (Elhennawy et al., 2017).

Kusurlar hafif, orta ve şiddetli olmak üzere üç sınıfa ayrılır. Bu sınıflandırmaya göre hafif derece BAKH bulguları; sürme sonrası kırık, çürük ve hassasiyet olmaksızın, sınırlı opasiteler, orta derece BAKH bulguları; sürme sonrası kırık, hassasiyet olmaksızın insizal/okluzal 1/3'te sınırlı opasiteler ile karakterizedir. Şiddetli derece BAKH'de ise opasiteler ile birlikte sürme sonrası oluşan kırıklar, hassasiyet, yaygın çürükler mevcuttur (Resim-5) (Yamaguti \& Cabral, 2019; Schuurs, 2013; Hazar Bodrumlu \& Avşar, 2015; Bilgin \& Pınar Erdem, 2016).

Daimî birinci büyük azı ve kesicilerin olgunlaşma periyodu, hamileliğin son trimestırı ile 0-3 yaş arasına denk geldiğinden bu dönemde geçirilmiş hastalıkların, kesin olmamakla birlikte, BAKH ile ilişkili olabileceği düşünülmektedir (Schuurs, 2013; Pınar Erdem, 2016). Prenatal dönemde sigara kullanımı, kimyasal etkenler, enfeksiyöz hastalıklar, perinatal dönemde erken doğum, düşük doğum kilosu, doğum komplikasyonları, postnatal dönemde malnutrasyon, su çiçeği gibi erken çocukluk dönemi hastalıkları, solunum yolu enfeksiyonu, kulak enfeksiyonu gibi nedenler BAKH ile ilişkili bulunmuştur (Yamaguti \& Cabral, 2019; Seow, 2014; Schwendicke et al., 2018).

BAKH'lı vakalara ikinci süt azı dişi hipomineralizasyonun da eşlik edebildiği ve birlikte görülme prevalansının \%19.94 olduğu bildirilmiştir (Elfrink et al., 2008). İkinci süt azısında hipomineralizasyon

$61 \mid \mathrm{P}$ a g e

www.iiste.org 
tespiti BAKH'nin erken tanısı ve koruyucu tedbirlerin alınmasında önemlidir (Garot et al.,2018). BAKH prevalansının dünya genelindeki prevalansının \%13.1 olarak belirtildiği bir çalışmada bu sayının ülkelerin popülasyon oranları ve gelişmişlik derecelerine göre değişebileceği vurgulanmaktadır (Schwendicke et al., 2018). Koruyucu ve arkadaşları çalışmalarında BAKH prevalansının Avrupa kaynaklı yayınlar baz alındığında dünya genelinde \%2.4 ile \%40.2 arasında değiştiğini belirtmişlerdir (Koruyucu et al., 2018).

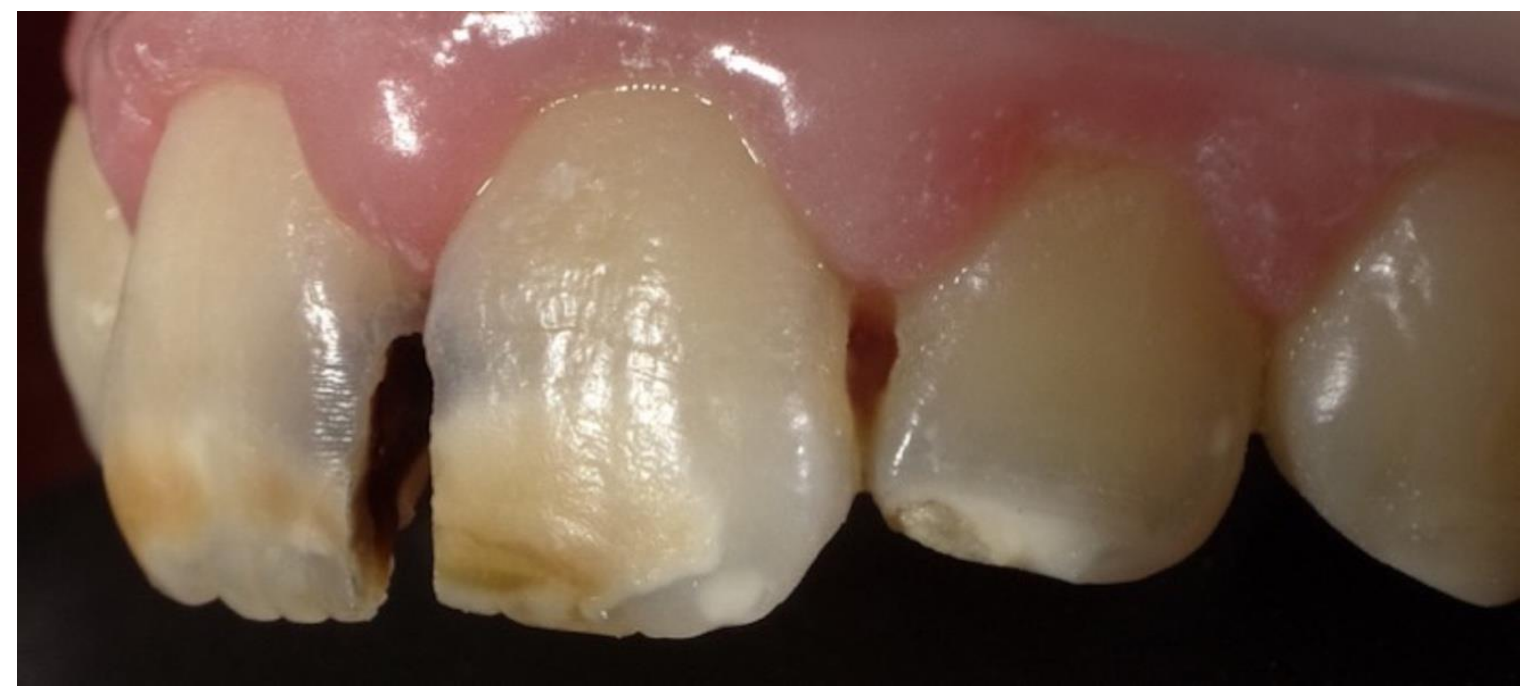

Resim 5: Büyük Azı-Kesici Diş Hipomineralizasyonlu dişlerde hızlı ilerleyen çürükler büyük doku kayıplarına neden olmakta, ön bölge dişlerinde ciddi estetik problemlere yol açmaktadır.

\subsection{Kalıtımsal Faktörlerin Neden Olduğu Gelişimsel Bozukluklar}

Mine gelişimi etkileyen kalıtsal faktörlerin çoğu sendromlardır, bu sendromlar ve kalıtsal hastalıklardan bazıları Tablo-2'de gösterilmektedir.

\begin{tabular}{|ll|}
\hline \multicolumn{1}{|c|}{ Tablo 2: Mine Gelişimi Etkileyen Kalıtsal Hastalıklar ve Sendromlar. } \\
\hline \multicolumn{1}{|c|}{ Hastalık } & \multicolumn{1}{|c|}{ Meydana gelen kusur } \\
\hline Psödoparatiroidizm & $\begin{array}{l}\text { GNAS genindeki defekt transkripsiyon faktörlerini } \\
\text { etkilemekte ve mine hipoplazisine neden olmaktadır (Wright } \\
\text { et al., 2015). }\end{array}$ \\
\hline Kleidokranial Displazi & $\begin{array}{l}\text { RUNX2 genindeki defekt transkripsiyon faktörlerini } \\
\text { etkilemekte ve mine hipoplazisine neden olmaktadır (Wright } \\
\text { et al., 2015). }\end{array}$ \\
\hline $\begin{array}{l}\text { Dentinogenesis İmperfekta } \\
\text { Tip III }\end{array}$ & $\begin{array}{l}\text { DSPP genindeki defekt biyomineralizasyonla alakalı iki } \\
\text { proteini etkilemekte ve mine hipoplazisi ile mine aplazisine } \\
\text { neden olmaktadır (Wright et al., 2015). }\end{array}$ \\
\hline Hipofosfatazi & $\begin{array}{l}\text { ALPL genindeki defekt membrana bağlı glikozile enzimi } \\
\text { etkileyip mine hipoplazisine neden olmaktadır (Wright et al., } \\
\text { 2015). }\end{array}$ \\
\hline Trikodentoosseöz Sendrom & $\begin{array}{l}\text { DLX3 genindeki mutasyon transkripsiyon faktörünü } \\
\text { etkilemekte ve displastik tırnaklar, kalınlaşmış kemik dokusu } \\
\text { ve taurodontizm ile eşlik eden mine hipoplazisiyle } \\
\text { seyretmektedir (Seow, 2014; Wright et al., 2015). }\end{array}$ \\
\hline
\end{tabular}




\begin{tabular}{|c|c|}
\hline Çölyak Hastalığı & $\begin{array}{l}\text { CELIACI genindeki defekt ekstraselüler proteinleri etkiler ve } \\
\text { mine hipoplazisine neden olur (Wright et al., 2015). Bu } \\
\text { hastalık gluten için seçici olan T hücresi aktivasyonu } \\
\text { nedeniyle ince bağırsak villöz mukozasının atrofisine yol } \\
\text { açmaktadır. Her iki dişlenmede de prizmalar hipomineralize, } \\
\text { kısa ve dağınık dizilimlidir (Seow, 2014; Schuurs, 2013). }\end{array}$ \\
\hline Epidermolizis Bullosa & $\begin{array}{l}\text { Deri ve mukozanın aşırı hassasiyeti sonucu kronik bül ve } \\
\text { erozyonlar oluşumu ile karakterize olan juntional } \\
\text { epidermolizis bülloza hastalığına neden olan COL7AI } \\
\text { genindeki mutasyon, hemidezmozom komponentlerini } \\
\text { etkilemektedir. Anormal üretilen proteinler nedeniyle } \\
\text { ameloblastlar birbirleri ile adezyon yapamaz bu durum hücre } \\
\text { ayrılmalarına ve generalize mine hipoplazilerine neden } \\
\text { olmaktadır (Nowak et al., 2019; Wright et al., 2015; Bayar \& } \\
\text { Ak, 2016). }\end{array}$ \\
\hline $\begin{array}{l}\text { X'e Bağlı Hipofosfatemik } \\
\text { Rikets }\end{array}$ & $\begin{array}{l}\text { PHEX genindeki defekt proteaz fonksiyonunu etkilemektedir. } \\
\text { Renal fosfor kaybı, anormal D vitamini metabolizması } \\
\text { nedeniyle alveol gelişimi ve kalsifikasyonu zayıftır, } \\
\text { periodontal ligament kaybı mevcuttur (Wright et al., 2015; } \\
\text { Sevinç et al., 2005). Mine çoğunlukla ince, sarı ve } \\
\text { hipoplastiktir veya diffüz hipokalsifiye alanlar içerir (Schuurs, } \\
\text { 2013) }\end{array}$ \\
\hline Galaktozemi & $\begin{array}{l}\text { GALT enziminin kalıtsal bozukluğu nedeniyle oluşan bu } \\
\text { hastalıkta karaciğer hasarı, gelişim geriliği, mental retardasyon } \\
\text { ve daimî dişlerde mine hipoplazisi gelişebilmektedir (Wright } \\
\text { et al., 2015; Schuurs, 2013). }\end{array}$ \\
\hline Orak Hücreli Anemi & $\begin{array}{l}\text { Akdeniz ülkelerinde görülme sıklığı yüksek olan bu otozomal } \\
\text { geçişli hastalıkta, hasarlı hemoglobin sentezi nedeniyle } \\
\text { eritrositler normalden uzun orak şeklinde ve esnek olmayan } \\
\text { formda oluşur, kılcal kan damarları tıkanır ve kan akımı } \\
\text { yavaşlar. Büyüme, gelişme geriliği meydana gelir ağız içi } \\
\text { bulgular hipokalsifiye mine ve dentin, tıkanmış dentin } \\
\text { kanalları, hipersementozis ile katakterizedir (Schuurs, 2013; } \\
\text { Söylemez et al., 2016). }\end{array}$ \\
\hline Fenilketonüri & $\begin{array}{l}\text { Fenilalaninin tirozine çevrilmesini sağlayan karaciğer enzimi } \\
\text { olan fenilalanin hidroksilazın kalıtsal eksikliğidir. Fenilalanin } \\
\text { birikimi beyin hasarı, mine hipoplazisi ve kahverengi } \\
\text { renkleşmelere neden olur (Schuurs, 2013). }\end{array}$ \\
\hline Okronozis & $\begin{array}{l}\text { Tirozin ve fenilalanin katabolizmasında görevli olan } \\
\text { homogentisik asit oksidaz enziminin kalıtsal eksikliği sonucu } \\
\text { vücutta homogentisik asit birikimdir (Aytuğ et al., 2002). Bağ } \\
\text { dokularının ve dişlerin rengi maviden siyaha değişir, mine } \\
\text { hipoplastik olabilir (Schuurs, 2013). }\end{array}$ \\
\hline
\end{tabular}




\begin{tabular}{|ll|}
\hline $\begin{array}{l}\text { Konjenital Eritropoetik Porfiri } \\
\text { (Günther Hastalığı): }\end{array}$ & $\begin{array}{l}\text { Artan porfirin sentezi ve atılımı nedeniyle süt dişlerinde } \\
\text { mine ve dentinde, daimî dişlerde dentinde porfirin birikimi } \\
\text { olur. Etkienen dişler kırmızı kahverengi renktedir (Neville } \\
\text { et al., 2015). }\end{array}$ \\
\hline Alkaptanüri & $\begin{array}{l}\text { Otozomal resesif geçişli bu metabolik hastalıkta dişler } \\
\text { mavi-siyah renktedir (Neville et al., 2015). }\end{array}$ \\
\end{tabular}

Amelogenesis İmperfekta: Etkisi diş ile sınırlı kalmış epitel doku hasarı veya mineralizasyon bozukluğu ile oluşan kalıtımsal mine defektlerinin genel adıdır (Seow, 2014). Amelogenesis imperfekta'nın sınıflandırılması histolojik, genetik, klinik ve radyografik kriterlere dayanmaktadır. En yaygın kullanılan sınıflandırma 1989 yılında Witkop tarafından fenotip (klinik görünüm) (Hipoplastik, Hipomatüre, Hipomineralize, Taurodontizmin eşlik ettiği hipomatüre-hipoplastik) ve kalıtım moduna (Otozomal resesif, otozomal dominant veya X e bağl1) dayalınarak oluşturulmuştur (Witkop, 1988). Amelogenesis imperfektanın prevalansı tüm dünyada değişiklik göstermektedir ve çalışılan popülasyona bağlı olarak 1/700-1/14000 arasında değişmektedir (Nowak et al., 2019; Moore \& Persaud, 2016; Crawford et al., 2007). Bunun yanında akraba evliliklerinin yaygın olduğu popülasyonlarda ortaya çıkma sıklığı artabilmektedir (Kammoun et al., 2019).

Klinik Görünümüne Göre Amelogenesis İmperfekta Tipleri (Resim-6):

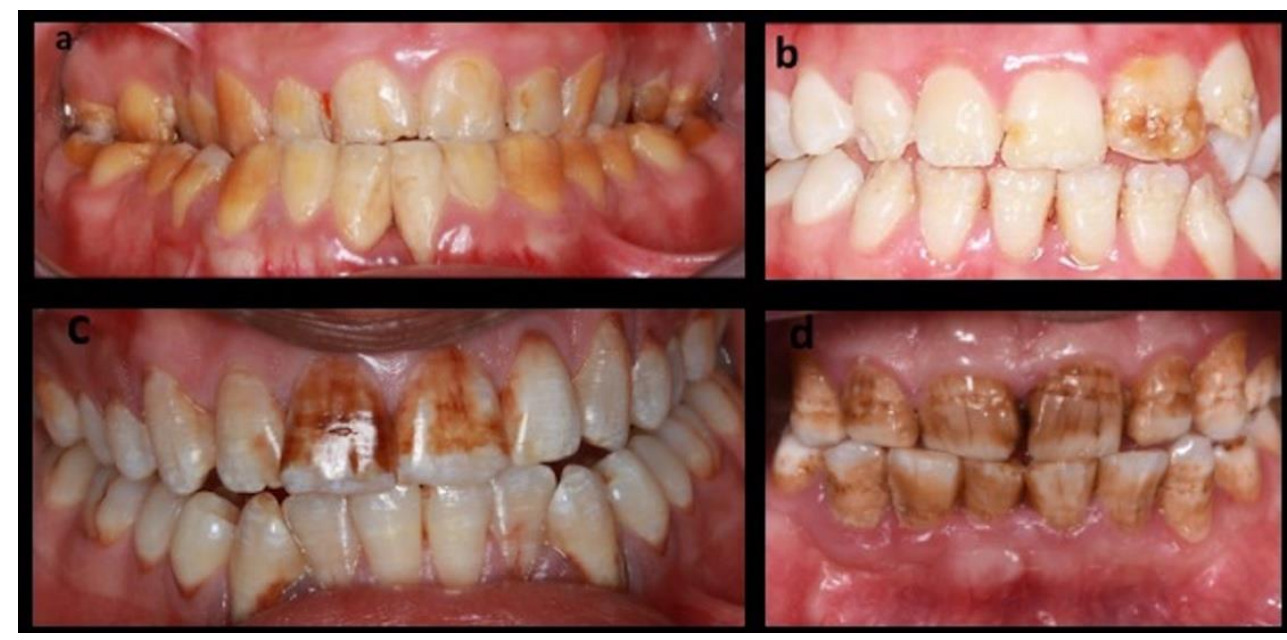

Resim 6: Amelogenesis İmperfekta lezyonlarının klinik görünümü: a. Hipomatür tip amelogenesis imperfekta, b. Hipoplastik tip amelogenesis imperfekta, c. Hipomineralize tip amelogenesis imperfekta, d. Hipomatür-hipoplastik tip amelogenesis imperfekta.

a. Hipolastik Amelogenesis İmperfekta: Sekresyon döneminde ameloblastların farklılaşma derecesi ve yaşam döngüsündeki aksaklık nedeniyle eksik miktarda mine matriksi birikimi olur. Belirgin özelliği minenin normalden ince olmasıdır, hiç oluşmadığı durumlar da olabilir. Mineralizasyon normaldir ve radyografide dentin ile minenin konstrast farklı normaldir. Alt tiplerine göre mine rengi sar1kahverengiden beyaza, yüzey özellikleri düzden, parlak veya pürüzlüye kadar değişir, diş köșeleri yuvarlak hatlıdır. Kalıtım şekli otozomal dominant, otozomal resesif veya X'e bağlı olabilmektedir (Chatzopoulos \& Tziafas, 2014; Neville et al., 2015; Schuurs, 2013; Ansari et al., 2018).

b. Hipomatüre Amelogenesis İmperfekta: Olgunlaşma döneminde protein rezorpsiyonundaki aksaklık nedeniyle, kristaller arasındaki mine matriksinin mineralizasyonun zayıf olması, mine prizmaları ve prizma mebranının hasarlı oluşmasıdır. Primer özellik minenin normal kalınlıkta ancak azalmış sertlikte 
olmasıdır. Kırılgan, alttaki dentinden sıyrılıp kopma eğiliminde ve çiğneme kuvvetlerine dirençsiz olan mine, sarımsı- kahverengi, kırmızımsı-kahverengi, opak-sarı, benekli-kahverengi renk değişimleri gösterir. Radyografide dentin-mine kontrastı birbirine yakındır. Kolayca aşınması nedeniyle dikey boyut kaybı, derin örtülü kapanış gibi maloklüzyonlara neden olur. Termal uyarılara karşı hassastır. Kalıtım şekli otozomal dominant, otozomal resesif veya X'e bağlı olabilir (Chatzopoulos \& Tziafas, 2014; Neville et al., 2015; Schuurs, 2013; Ansari et al., 2018; Barzotto \& rigo, 2018).

c. Hipomineralize Amelogenesis İmperfekta: Normal miktarda oluşan mine matriksinde, mineralizasyon fazına geçildiğinde protein yıkımının gerçekleşememesi nedeniyle yetersiz kalsifikasyon meydana gelmektedir. Önemli miktarda amelogenin ve albumin içermektedir. Mine yaklaşı \%10 civarında organik madde içerir, normal mineden \%30 oranında daha az kalsifiyedir. Diş sürdüğünde normal kalınlıkta olan mine yüzeyi çok yumuşaktır ve künt bir el aletiyle bile kolayca kırılabilir. Özellikle tüberkül tepelerinde fonksiyon nedeniyle mine kolaylıkla ortadan kalkar, yüzey düzensizleşir. Termal uyarılara karşı hassastır. Sürerken mine sarı-kahverengi veya turuncu renktedir ancak zamanla kahverengi-siyah renkleşme olur ve hızlı bir diş taşı birikimi vardır. Radyografide mine dentin yoğunlukları birbirine yakındır (Chatzopoulos \& Tziafas, 2014; Neville et al., 2015; Schuurs, 2013; Ansari et al., 2018).

d. Taurodontizmin Eşlik Ettiği Hipomatüre-Hipoplastik Amelogenesis İmperfekta: Bu tip ilk olarak 1970'de Crawford tarafindan tanımlanmıştır ve 1975 'te Winter ve Brook tarafindan yapılan sınıflandırmada ayrı bir alt tip olarak belirtilmiştir. Mine ince, yumuşak ve kırılgandır. Yüzeyi çukurcukludur ve sarı-kahverengi benekler içerir. Radyografide mine dentin yoğunluğu benzerdir, geniş pulpa odalı tek köklü dişler ve değişik derecelerde taurodontizm söz konusudur. Minedeki porlar \%25 oranında genişlemiştir (Neville et al., 2015; Schuurs, 2013).

Amelogenesis imperfektada genellikle her iki diş dizisi de etkilenir ve bir dizideki tüm dişler kusurludur. Her gen çeşitli yollarla mutasyona uğrayabilmekte, farklı fenotipte özellikler yaratabilmektedir. Yapılan çalışmalarda 15 'ten fazla genin mutasyonu amelogenesis imperfekta ile iliş̧ili bulunmuştur (Kwon \& Jiang, 2018; Zhang et al., 2019).

Tablo-3'te Online Mendelian Inheritance in Man (OMIM) genetik veri tabanı ve amelogenesis imperfekta ile ilgili yapılan genetik çalışmalardan yararlanılarak hazırlanmış gen-fenotip ve kalıtım modu ilişkili sınıflandırma modifikasyonu gösterilmektedir.

\begin{tabular}{|c|c|c|c|c|}
\hline \multicolumn{5}{|c|}{$\begin{array}{l}\text { Tablo 3: Gen ve Fenotip İlişkili Amelogenesis İmperfekta Sinıflandırması. } \\
\text { (Neville et al., 2015; Seow, 2014; Nowak et al., 2019; Zhang et al., 2019; Wright et al., 2011; Witkop et al., 1976; } \\
\text { Chosack et al., 1979; Poulter et al., 2014; Wang et al., 2013; Kim et al., 2005; Parry et al., 2012; Mendoza et al., } \\
\text { 2007; Smith et al., 2016; Kim et al., 2019) }\end{array}$} \\
\hline Fenotip & Kalıtım Modu & $\begin{array}{l}\text { Sorumlu } \\
\text { Protein }\end{array}$ & $\begin{array}{l}\text { Kodlayan Gen; } \\
\text { OMIM Numarası } \\
\text { (Kromozom } \\
\text { Lokasyonu) }\end{array}$ & Klinik Bulgu \\
\hline $\begin{array}{l}\text { Tip IA } \\
\text { (Hipoplastik) }\end{array}$ & $\begin{array}{l}\text { Otozomal } \\
\text { Dominant }\end{array}$ & $\begin{array}{l}\text { Beta-3 laminin; } \\
\text { bazal membran } \\
\text { proteini }\end{array}$ & $\begin{array}{l}\text { LAMB3; } 150310 \\
(1 q 32.2)\end{array}$ & $\begin{array}{l}\text { Hipoplastik, ince mine yapısı. Generalize } \\
\text { çukurcuk ve oluklar mine yüzeyinde } \\
\text { dağınıktır. } \\
\text { Hipersensitivite mevcut olabilir. } \\
\text { Sürme sonrasında aşınma eğilimindedir. } \\
\text { Radyografide mine-dentin kontrast farkı } \\
\text { vardır. }\end{array}$ \\
\hline $\begin{array}{l}\text { Tip IB } \\
\text { (Hipoplastik) }\end{array}$ & $\begin{array}{l}\text { Otozomal } \\
\text { Dominant }\end{array}$ & $\begin{array}{l}\text { Enamelin; } \\
\text { matriks proteini }\end{array}$ & $\begin{array}{l}\text { ENAM; } \\
606585 \\
(4 q 13.3)\end{array}$ & $\begin{array}{l}\text { Hipoplastik, ince mine yapısı. Bukkal } \\
\text { yüzeyin orta } 1 / 3 \text { 'ünde lokalize, yatay } \\
\text { sıralı çukurcuk ve oluklar mevcuttur. } \\
\text { İnsizal veya okluzal yüzey } \\
\text { etkilenmemiştir. }\end{array}$ \\
\hline $\begin{array}{l}\text { Tip IC } \\
\text { (Hipoplastik) }\end{array}$ & $\begin{array}{l}\text { Otozomal } \\
\text { Resesif }\end{array}$ & $\begin{array}{l}\text { Enamelin; } \\
\text { matriks proteini }\end{array}$ & $\begin{array}{l}\text { ENAM; } \\
606585 \\
(4 q 13.3)\end{array}$ & $\begin{array}{l}\text { Hipoplastik, ince mine yapısı. Bukkal } \\
\text { yüzeyin orta 1/3'ünde lokalize, yatay } \\
\text { sıralı çukurcuk ve oluklar mevcuttur. } \\
\text { Yetersiz mineralizasyon ve sarı- } \\
\text { kahverengi renkleşmeler vardır. Ön açık } \\
\text { kapanıs, mandibulada retrognati eşlik } \\
\text { edebilmektedir. }\end{array}$ \\
\hline
\end{tabular}




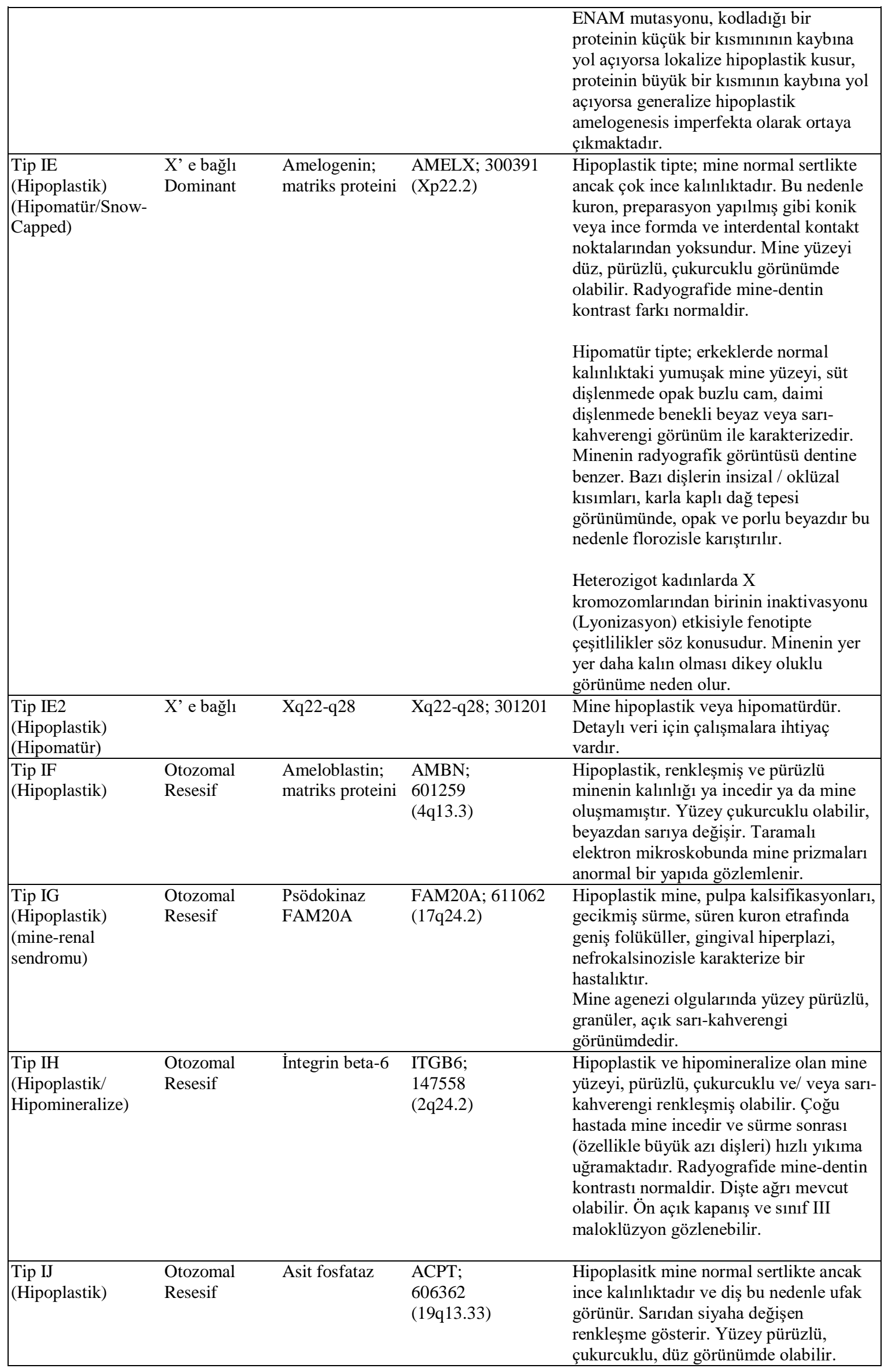




\begin{tabular}{|c|c|c|c|c|}
\hline & & & & $\begin{array}{l}\text { Termal uyarana duyarlı, interdental } \\
\text { kontaktlardan yoksundur. Derin örtülü } \\
\text { kapanış eşlik edebilir. }\end{array}$ \\
\hline \begin{tabular}{|l|} 
Tip IIA1 \\
(Hipomatür/ \\
Pigmentli)
\end{tabular} & $\begin{array}{l}\text { Otozomal } \\
\text { Resesif }\end{array}$ & $\begin{array}{l}\text { Kallikrein-4, } \\
\text { matriks } \\
\text { proteinaz1 }\end{array}$ & $\begin{array}{l}\text { KLK4; } \\
603767 \\
(19 q 13.41)\end{array}$ & $\begin{array}{l}\text { Hipomatür mine normal kalınlıkta ancak } \\
\text { yumuşaktır. Dentinden kolayca } \\
\text { ayrılabilir. Dişlerde homojen benekli } \\
\text { koyu sarı renkleşmeler vardır. Sıcak ve } \\
\text { soğuk hassasiyeti vardır. Ön açık kapanış } \\
\text { gözlenebilir. Radyografide kontrast farkı } \\
\text { çok azdır. İnsizal ve okluzaldeki mine } \\
\text { yüzeyi kaba çukurcuklar halindedir. En } \\
\text { iyi mineralize mine dentine yakın olandır, } \\
\text { kristallerin etrafını kalın bir organik kılıf } \\
\text { çevreler. }\end{array}$ \\
\hline $\begin{array}{l}\text { Tip IIA2 } \\
\text { (Hipomatür/ } \\
\text { Pigmentli) }\end{array}$ & $\begin{array}{l}\text { Otozomal } \\
\text { Resesif }\end{array}$ & $\begin{array}{l}\text { Matrix } \\
\text { Metalloproteina } \\
\text { z-20; } \\
\text { matriks } \\
\text { proteinaz1 }\end{array}$ & $\begin{array}{l}\text { MMP20; } 604629 \\
(11 q 22.2)\end{array}$ & $\begin{array}{l}\text { Hipomatür mine normal kalınlıkta ancak } \\
\text { yumuşaktır. Dentinden kolayca } \\
\text { ayrılabilir. Dişlerde yüzey pürüzlüdür, } \\
\text { düzensiz dağılımlı sarımsı kahverengi } \\
\text { veya benekli esmer şeker benzeri } \\
\text { renkleşmeler vardır. Hipersensitivite } \\
\text { vardır. Ön açık kapanış gözlenebilir. } \\
\text { Radyografide kontrast farkı çok azdır. }\end{array}$ \\
\hline $\begin{array}{l}\text { Tip IIA3 } \\
\text { (Hipomatür) }\end{array}$ & $\begin{array}{l}\text { Otozomal } \\
\text { Resesif }\end{array}$ & $\begin{array}{l}\text { WDR72; } \\
\text { intraselüler } \\
\text { protein }\end{array}$ & $\begin{array}{l}\text { WDR72; } 613214 \\
(15 \mathrm{q} 21.3)\end{array}$ & $\begin{array}{l}\text { Hipomatür mine pürüzlüdür ve sürme } \\
\text { sonrası aşınmaya çok eğilimlidir. } \\
\text { Sürdüğünde opak veya krem renginde } \\
\text { olabilir sonradan renkleşme olur. Termal } \\
\text { ve fiziksel uyaranlara hassastır. } \\
\text { Radyografide kontrast farkı çok azdır. }\end{array}$ \\
\hline $\begin{array}{l}\text { Tip IIA4 } \\
\text { (Hipomatür) }\end{array}$ & $\begin{array}{l}\text { Otozomal } \\
\text { Resesif }\end{array}$ & $\begin{array}{l}\text { Odontogenezle } \\
\text { ilişkili } \\
\text { fosfoprotein; } \\
\text { ekstraselülar } \\
\text { matrix proteini }\end{array}$ & $\begin{array}{l}\text { C4orf26; } 614829 \\
(4 q 21.1)\end{array}$ & $\begin{array}{l}\text { Hipomatür minede parsiyel hipoplazi de } \\
\text { vardır. Sarımsı kahverengi renktedir. } \\
\text { Sürme sonrası aşınmaya çok eğilimlidir. } \\
\text { Radyografide dentinle kontrast farkı } \\
\text { yoktur. }\end{array}$ \\
\hline $\begin{array}{l}\text { Tip IIA5 } \\
\text { (Hipomatür) }\end{array}$ & $\begin{array}{l}\text { Otozomal } \\
\text { Resesif }\end{array}$ & $\begin{array}{l}\text { Sodyum, } \\
\text { potasyum, } \\
\text { kalsiyum taş1yıcı } \\
\text { membran } \\
\text { proteini }\end{array}$ & $\begin{array}{l}\text { SLC24A4; } 609840 \\
(14 q 32.12)\end{array}$ & $\begin{array}{l}\text { Hipomatüre mine normal kalınlıkta ancak } \\
\text { yumuşak, sarımsı kahverengi renktedir. } \\
\text { Sürme sonrası aşınmaya eğilimlidir. } \\
\text { Radyografide dentinle kontrast farkı } \\
\text { yoktur. }\end{array}$ \\
\hline $\begin{array}{l}\text { Tip IIA6 } \\
\text { (Hipomatür) }\end{array}$ & $\begin{array}{l}\text { Otozomal } \\
\text { Resesif }\end{array}$ & $\begin{array}{l}\text { G protein kenetli } \\
\text { reseptör } 68\end{array}$ & $\begin{array}{l}\text { GPR68; } \\
601404 \\
(14 q 32.11)\end{array}$ & $\begin{array}{l}\text { Hipomatür mine opak-krem renklidir } \\
\text { zamanla sarımsı-kahverengi renkleşmeye } \\
\text { uğrar. Lokalize pürüzlülük ve } \\
\text { hipomineralizasyonlar vardır. Kırılmaya } \\
\text { meğillidir. Radyografide dentinle } \\
\text { kontrast fark1 yoktur. }\end{array}$ \\
\hline \begin{tabular}{|l} 
Tip IIIA \\
(Hipomineralize)
\end{tabular} & $\begin{array}{l}\text { Otozomal } \\
\text { Dominant }\end{array}$ & $\begin{array}{l}\text { FAM83H; } \\
\text { intraselüler } \\
\text { matriks proteini }\end{array}$ & $\begin{array}{l}\text { FAM83H; } 611927 \\
\text { (8q24.3) }\end{array}$ & $\begin{array}{l}\text { Hipokalsifiye mine normal kalınlıkta } \\
\text { ancak peynir kıvamında bir } \\
\text { yumuşaklıktadır. Krem beyaz, sarıms1 } \\
\text { renktedir. Minenin mineral oranı hacimce } \\
\% 40 \text { ile } \% 70 \text { arasında değişmektedir. } \\
\text { Dişler sürdüğü gibi mine yıkımı olur. } \\
\text { Vakaların \%60'ında ön bölge açı } \\
\text { kapanış mevcuttur. Radyografide mine } \\
\text { dentinden daha radyolusenttir ve güve } \\
\text { yeniği görüntüsü vardır. }\end{array}$ \\
\hline \begin{tabular}{|l|} 
Tip IIIB \\
(Hipomineralize)
\end{tabular} & $\begin{array}{l}\text { Otozomal } \\
\text { Dominant }\end{array}$ & Amelotin & $\begin{array}{l}\text { AMTN; } \\
617607 \\
(4 q 13.3)\end{array}$ & $\begin{array}{l}\text { Hipomineralize mine ince, yer yer } \\
\text { kırılmış veya tamamen ortadan kalkmış } \\
\text { durumdadır. Taramalı elektron } \\
\text { mikroskobunda kusurlu alanlardaki } \\
\text { prizmatik yapının boğumlu görünüm } \\
\text { sergilediği bildirilmiştir. }\end{array}$ \\
\hline Tip IIIC & Otozomal & RELT & RELT; & Hipokalsifiye mine yüzeyi pürüzlü, sar1- \\
\hline
\end{tabular}




\begin{tabular}{|c|c|c|c|c|}
\hline (Hipomineralize) & Resesif & & $\begin{array}{l}611211 \\
(11 q 13.4)\end{array}$ & $\begin{array}{l}\text { kahverengi, amber renklidir. Özellikle } \\
\text { çiğneme yüzeylerindeki mine aşınır. Ön } \\
\text { açık kapanış olabilir. }\end{array}$ \\
\hline $\begin{array}{l}\text { Tip IV } \\
\text { (Taurodontizmin } \\
\text { eşlik ettiği } \\
\text { hipomatür- } \\
\text { hipoplastik) }\end{array}$ & $\begin{array}{l}\text { Otozomal } \\
\text { Dominant }\end{array}$ & $\begin{array}{l}\text { Homeobox } \\
\text { proteini DLX-3 }\end{array}$ & $\begin{array}{l}\text { DLX3; } \\
600525 \\
(17 q 21.33)\end{array}$ & $\begin{array}{l}\text { DLX3 geni: diş, kraniyofasiyal, beyin, } \\
\text { nöral gelişim ile alakalı bir grup proteini } \\
\text { kodlar. Dental bulgulara ilave olarak } \\
\text { kafatası ve mastoid proceste osteoskleroz, } \\
\text { kırılgan tırnaklar, dağınık dolaşı saç } \\
\text { yapısı, kısa ve geniş açılı ramus gibi } \\
\text { sistemik bulgular mevcuttur. }\end{array}$ \\
\hline
\end{tabular}

\section{Gelişimsel Mine Kusurlarının Diagnozu ve Ayırıcı Tanı Kriterleri}

Gelişimsel mine kusurlarının benzer klinik özelliklere sahip olması nedeniyle doğru bir değerlendirme ve tanı prosedürünün gerçekleştirilebilmesi için klinik ve radyografik muayenelerin dikkatli bir şekilde yapılması, dental ve sistemik anamnezlerin eksiksiz olarak alınması gerekmektedir. Ayırıcı tanılar ve etiyolojik faktörlerin doğru değerlendirilmesi, sağlıklı mine dokusu, çürük lezyon ve mine kusurlarının birbirinden ayırt edilmesi için çok önemlidir (Barzotto \& Rigo, 2018). Kusurun meydana getirdiği klinik komplikasyonların rehabilitasyonu için gerekli olan tedavi seçeneğine karar verilebilmesi ve bu tedavilerin başarısının değerlendirilebilmesi için klinik fotoğraflama, ölçü alımı ve radyografi ile hastanın kayıt altına alınması gerekmektedir (Cochran et al., 2004).

Klinik muayene optimal aydınlatma altında kusurları maskeleyecek olan tükürük ve dental plak profilaksi patıyla kaldırılarak, diş temiz ve nemliyken yapılmalıdır. Radyografik muayene ile dokunun kalınlığı ve mineralizasyonun derecesi, pulpa odasında kalsifikasyon varlığı, köklerin morfolojisi tespit edilmelidir (Barzotto \& Rigo, 2018; Cochran et al., 2004).

Belirli bir diş grubunda mevcut olan difüz opasitelerin maturasyon zamanındaki sistemik bir etkenden kaynaklandığı düşünülmelidir. Ancak sınırlı opasiteler veya lokalize hipoplazili dişler etkenin lokal ve geçici olduğunu gösterir. Tüm süt dişlerinin etkilendiği kusurların genetik nedenli olabileceği düşünülmelidir, bu durum daimî dişlenmede ortaya çıabilecek gelişimsel mine defektleri için indikatör olabilir (Weerheijm, 2004).

Bilateral, difüz ve simetrik opasitelere sahip olan bir hastanın, çocukluk döneminde kronik olarak aşırı miktarda florür alımı olup olmadığı sorgulanmalıdır. Florozis lezyonları, opak mine kusurları görünüm itibariyle başlangıç mine çürükleriyle karıştırılabilmektedir. Başlangıç mine çürükleri genellikle dental plak ile çevrili, iyi sınırlı ve gingival marjine komşu bir konumda iken opak mine kusurlarının standart bir lokalizasyonu yoktur (Barzotto \& Rigo, 2018; Cochran et al., 2004).

Yalnızca birinci büyük azılar ve kesici dişlerde lokalize olmuş lezyonlar ve hastada çocukken geçirilmiş ateşli hastalık öyküsü BAKH tanısı açısından önemlidir. Avrupa Pediatrik Dişhekimliği Birliği (EAPD) tarafindan belirlenen teşhis metodlarına göre BAKH'li olduğu düşünülen hastalarda klinik muayene dişler temiz ve nemli iken yapılmalıdır. Dişlerde sınırlı opasite varlığı, sürme sonrası oluşan mine kırıkları ve atipik restorasyon mevcudiyeti, BAKH nedenli olabilecek çekilmiş diş varlığı, büyük azı veya kesicilerde sürme bozukluğu olup olmadığı araştırılmalıdır (Yamaguti \& Cabral, 2019; Schuurs, 2013; Hazar Bodrumlu \& Avşar, 2015). İkinci süt azı dişleri ile daimî kesici ve birinci büyük azı dişlerinin gelişim dönemlerinin birbiri ile çakışması nedeniyle, ikinci süt azı dişlerinde hipomineralizasyon varlığı BAKH için indikatör olabilmektedir (Weerheijm, 2004).

Florozis ve BAKH'nin ortak özelliği sürme sonrası, fonksiyona bağlı olarak, minede meydana gelen kırıklardır. Bu mine kırıklarını hipoplastik mineden ayırt etmek önemlidir, hipoplastik mine düzgün ve yumuşak geçişlidir, hipomineralize minenin zamanla kırılması sonrası oluşan görüntü ise düzensiz keskin kenarlıdır. Amelogenesis imperfektada hem süt hem daimî dişler etkilenmektedir. Bunun yanında; aile bireylerinde amelogenesis imperfekta mevcut olması, aşırı hipersensitivite, dikey boyut kaybı, kuronun preparasyon yapılmış gibi konik formda olması ve interproksimal alanlarda kontakt olmaması, iskeletsel ön açık kapanış, radyografide süt dişi retansiyonu veya alveol kemiği içinde rezorbe olmuş sürmemiş dişler, mine ve dentin kontrastının yakın veya aynı olması, taurodontism gibi özellikler amelogenesis imperfekta ile birlikte yaygın olarak gözlenir ve diagnoz sırasında göz önünde bulundurulmalıdır. Aile bireylerinde amelogenezis imperfekta öyküsü veya epidermiolizis bülloza, serebral palsi veya prematür doğum gibi mine kusurlarıyla ilişkili tıbbi durumlar da mine kusurları açısından değerlendirilmelidir (Yamaguti \& Cabral, 2019). 


\section{Minimal İnvaziv Tedavi Seçenekleri}

Tedavi seçenekleri Tablo-4’te gösterilmektedir.

Tablo 4. Gelişimsel Mine Kusurlarında Minimal İnvaziv Tedavi Seçenekleri.

(Barzotto \& Rigo, 2018; Patel et al., 2019; Willmott et al., 2008)

\begin{tabular}{|ll|}
\hline $\begin{array}{l}\text { 1. Koruyucu ve Önleyici } \\
\text { Tedaviler }\end{array}$ & $\begin{array}{l}\text { 3-6 ayda bir uygulanan topikal florür preparatları (Nötral Sodyum } \\
\text { Florid jel, Florid vernik), florürlü diş macunu (5000 ppm), florürlü } \\
\text { gargara (225 ppm), kazein fosfopeptid - amorf kalsiyum fosfat } \\
\text { (CCP-ACP) içerikli ajanlar, reçine veya cam iyonomer esaslı } \\
\text { fissür örtücülerin uygulanması. }\end{array}$ \\
\hline 2. Minimal İnvaziv Tedaviler & $\begin{array}{l}\text { Mikroabrazyon, ofis tipi beyazlatma, reçine infiltrasyon tekniği, } \\
\text { direkt kompozit restorasyon uygulamaları. }\end{array}$ \\
\hline 3. İndirekt Tedaviler & $\begin{array}{l}\text { Laminate veneer, inlay-onlay restorasyonları, kuron } \\
\text { restorasyonları }\end{array}$ \\
\hline
\end{tabular}

Gelişimsel mine kusurlu dişlerde, taramalı elektron mikroskobu (SEM) altında incelenen subklinik poröz mine alanlarında tespit edilen karyojenik bakteri kolonizasyonları, bu defektlerde başlangıç çürüklerinin daha kolay oluştuğunu göstermektedir. Hipoplazik defektlerdeki ince mine dokusu, asitte çözünmeye normal mineden daha dirençsiz ve dental plak için retantif olması nedeniyle çürük ile aşınma açısından risk faktörüdür. Bu defektere sahip hastalarda çürük ve aşınmaların önlenebilmesi için antikaryojenik beslenme ve asidik gıdalardan kaçınılması önerilmelidir (Weerheijm, 2004).

Gelişimsel mine kusurlu tüm hastalarda ortak şikâyet, hipomineralizasyon veya dentinin açığa çıkması kaynaklı hipersensitivitedir. Bu durum nedeniyle oral hijyenin yeterli düzeyde sağlanamaması, zayıf yapıdaki mine dokusunun fonksiyonel kuvvetlerle kaybı bireylerinde yüksek çürük insidansına yol açmaktadır. Defektin tespiti ile birlikte hastalara 1lık su ve yumuşak kıllı diş firçası ile firçalama, hassasiyet giderici diş macunu kullanımı ve gargaraların kullanımı önerilmesi ile hassasiyet şikayetinin azaltılması, hastanın oral hijyen alışkanlıklarının normalize edilmesi ve periodontal sağlığının yerine getirilmesi çürük insidansının azaltılması açısından önem teşkil etmektedir. Topikal florid uygulamaları, kalsiyum ve fosfat rezervuarı görevi gören CPP - ACP gibi remineralizasyon ajanları, hipomineralize alanların ve başlangıç çürüklerinin remineralizasyonunu sağlayarak ve bakteri adezyonunu önleyerek başlangıç çürüklerinin ve doku kayıplarının ilerlemesinin engellenmesine yardımc1 olmaktadır (Seow,2014; Weerheijm, 2004; Patel et al., 2019).

Lokalize veya generalize hipoplazi vakalarında, özellikle genç hastalarda, en iyi restorasyon seçeneği direkt kompozitlerdir (Resim-7,8). Gelişmiş adeziv materyaller sayesinde konservatif yöntemle estetik ve fonksiyonel tedaviler tek seansta, minimum doku kaybıyla doğal dokular taklit edilerek başarıyla gerçekleştirilmektedir (Barzotto \& Rigo, 2018). 


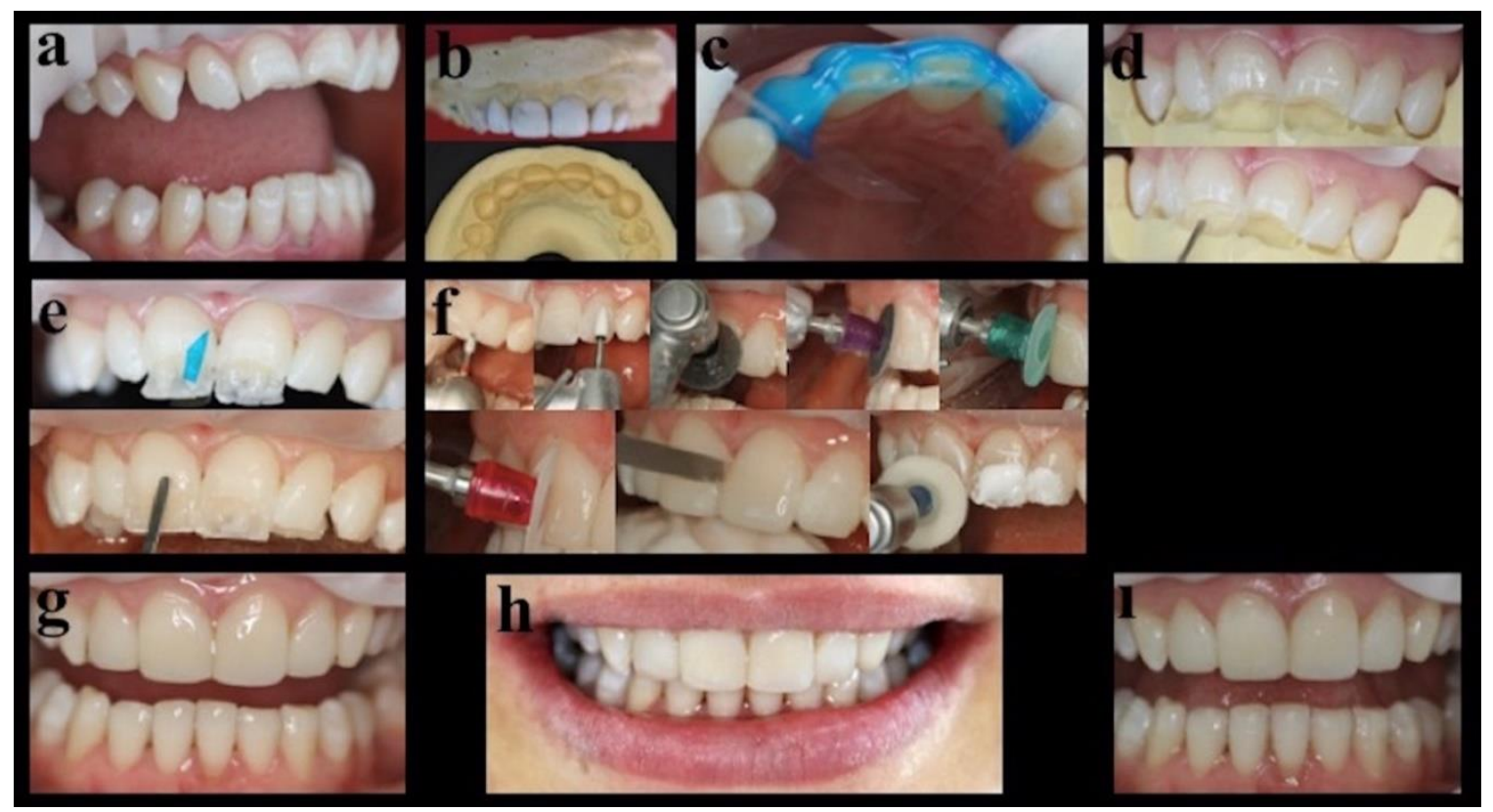

Resim 7: Mine hipoplazili dişlerin direkt kompozit reçine restorasyonlarla rehabilitasyonu: a.

Generalize mine hipoplazisinin klinik görünümü, b. Wax-up ve silikon anahtar oluşturulması, c.

Lezyon ve renkleşmelerin kaldırılmasının ardından minenin selektif olarak asitle pürüzlendirilmesi, $d$. Silikon anahtar ile palatinal duvarların oluşturulması (Beautifil II, A2 Body, Shofu, Kyoto, Japan), e. Dentin dokusu ve mamelonların oluşturulması (Beautifil II, A2O Shade, Shofu, Kyoto, Japan), bukkal mine yüzeyinin oluşturulması (Beautifil II, A2 Body, Shofu, Kyoto, Japan), f. Cila prosedürlerinin gerçekleştirilmesi (Super Snap Rainbow Technique Kit, Shofu, Kyoto, Japan), g. Restorasyonun bitimi sonrası görünüm, h. ve 1.1 yıllık kontrol ağız dışı ve ağız içi görüntüsü.

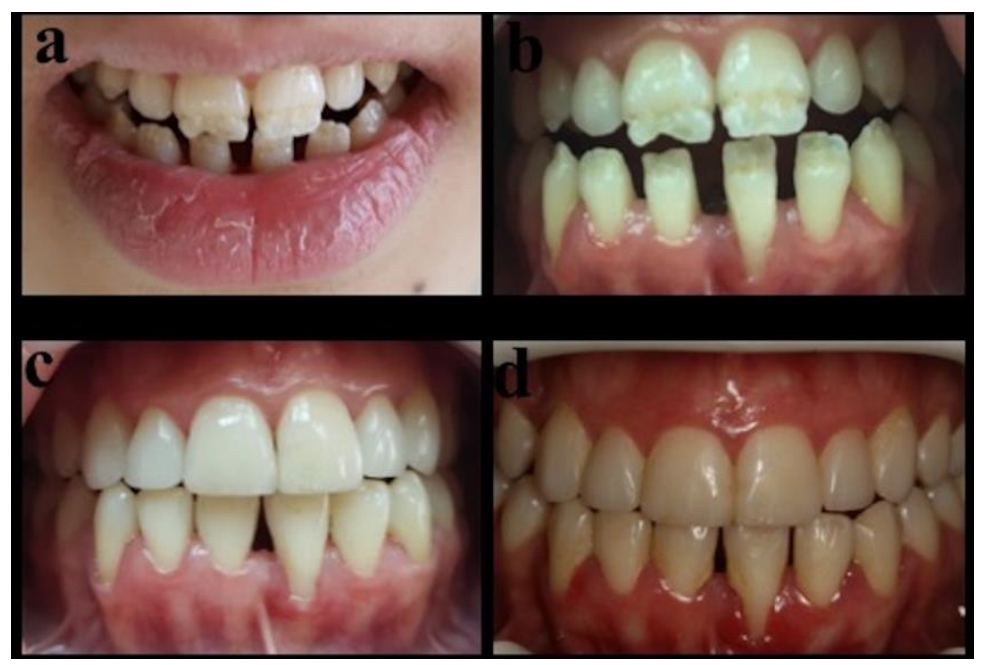

Resim 8: Mine hipoplazili dişlerin direkt kompozit reçine restorasyonlarla rehabilitasyonu: a. ve b. Lokalize mine hipoplazisinin ağız dışı ve ağız içi görünümü. Renk seçimi yapıldıktan sonra rubberdam izolasyonu sağlandı. Minedeki opak lezyonlar yeşil kuşaklı elmas labut frezle uzaklaştırıldı. Mine yüzeyleri 15 sn \%35'lik ortofosforik asit (Scotchbond Universal Etchant, 3M ESPE, St Paul, MN, USA) ile pürüzlendirildi, universal dentin adezivi (Scotchbond Universal, 3M ESPE, St Paul, MN, USA) üretici firma önerileri doğrultusunda uyguland1. Restorasyonlar A2-Body/A2-Mine renkli nanofil reçine kompozit (Filtek Ultimate Universal, 3M ESPE, St Paul, MN, USA) ile tamamlandı. Bitim ve cila işlemleri sırasıyla, kırmızı-sarı bantlı cila frezleri ve alüminyum oksit kaplı cila diskleri (Sof-Lex System, 3M ESPE, St Paul, MN, USA) ile gerçekleştirildi. c. Bitimden 1 hafta sonra ağız içi görüntüsü, d. 18 aylık ağız içi görüntüsü, üst çene sol santral dişin vestibül yüzeyi FDI kriterlerine göre marjinal renklenme ve restorasyon bütünlüğü açısından Skor 2 olarak değerlendirilmiştir. 
Florozis hastalarında şikâyet genellikle ön dişlerdeki estetik kusurdur. Renkleşme olmayan ve estetik probleme yol açmayan hafif florozis olgularında tedavi gerekmemektedir (Barzotto \& Rigo, 2018). Florozisin derecesine, hastanın yaşına ve şikayetine bağlı olarak beyazlatma, mikroabrazyon, reçine infiltrasyonu, direkt kompozit restorasyonlar gibi sert dokunun korunmasına yönelik minimal invaziv yaklaşımlar, farklı kombinasyonlarla başarı ile uygulanabilmektedir (Resim-9) (Yamaguti \& Cabral, 2019; Schuurs, 2013).

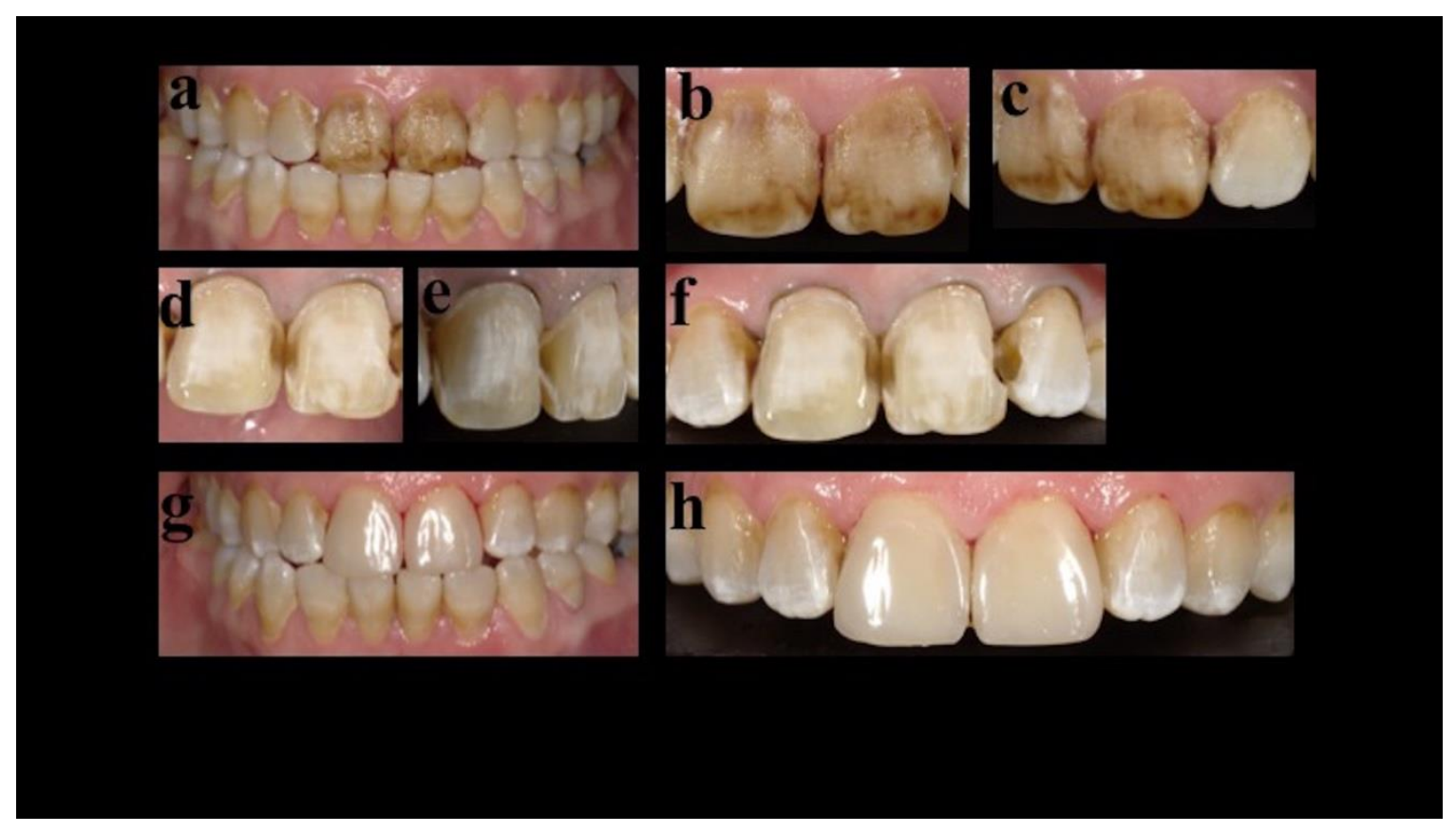

Resim 9. Florozisli dișleri direkt kompozit reçine restorasyonlarla rehabilitasyonu: a. Üst ve alt çenenin başlangıç klinik görünümü, generalize beyaz opasiteler, b. Üst çene nn dişlerde kahverengi renkleşme, c. Sınıf 3 çürük mevcudiyeti, d. Üst çene sağ ve sol santral dişlerin bukkal yüzeyindeki hipomineralize lezyonun ve çürügüun tamamen uzaklaştırılması, e. Üst çene sol lateral dişteki çürük lezyonun tamamen uzaklaştırılması, f. Self-etch adeziv sistem (Clearfil SE bond, Kuraray, Tokyo, Japan) uygulanan üst çene sağ ve sol santral dişlere direkt kompozit vener (Clearfil Majesty ES-2 Classic A2 Body, Kuraray, Tokyo, Japan), üst çene sol lateral dişe sınıf 3 kompozit restorasyon uygulanması (Clearfil Majesty ES-2 Classic A2 Body, Kuraray, Tokyo, Japan) sonrası bitim ve cila işlemleri elmas emdirilmiş cila spiralleri (Clearfil Twist Dia, Kuraray Europe Gmbh, Hattersheim am

Main, Germany) ile gerçekleştirilmiştir. g. ve h. restorasyon bitimi sonrası ağı içi görünüm.

Floroziste yüzeyel kahverengi lezyonlar, düşük devirli dönen enstrüman kullanılarak uygulanan mikroabrazyon (pomza patı ve HCL jel) ile uzaklaştırılmaktadır. Ofis tipi beyazlatma uygulamasında (H2O2 ile) oluşan peroksit iyonları mine ve dentine penetre olmakta ve sağlıklı mine ile beyaz hipomineralizasyon opasiteleri arasındaki kontrast farkının azalmasını sağlamaktadır (Resim-10). Bu prosedürler sonrasında uygulanacak olan reçine infiltrasyonu tekniği ile de yüzey altındaki mikroporözitelere penetre olan 1şıkla sertleşen düşük viskositeli reçinenin refraktif indeksinin mineye yakın olması ile opasiteler maskelenebilmekte ve başlangıç çürük lezyonları durdurulabilmektedir (Di Giovanni et al., 2018; Munoz et al., 2013). 


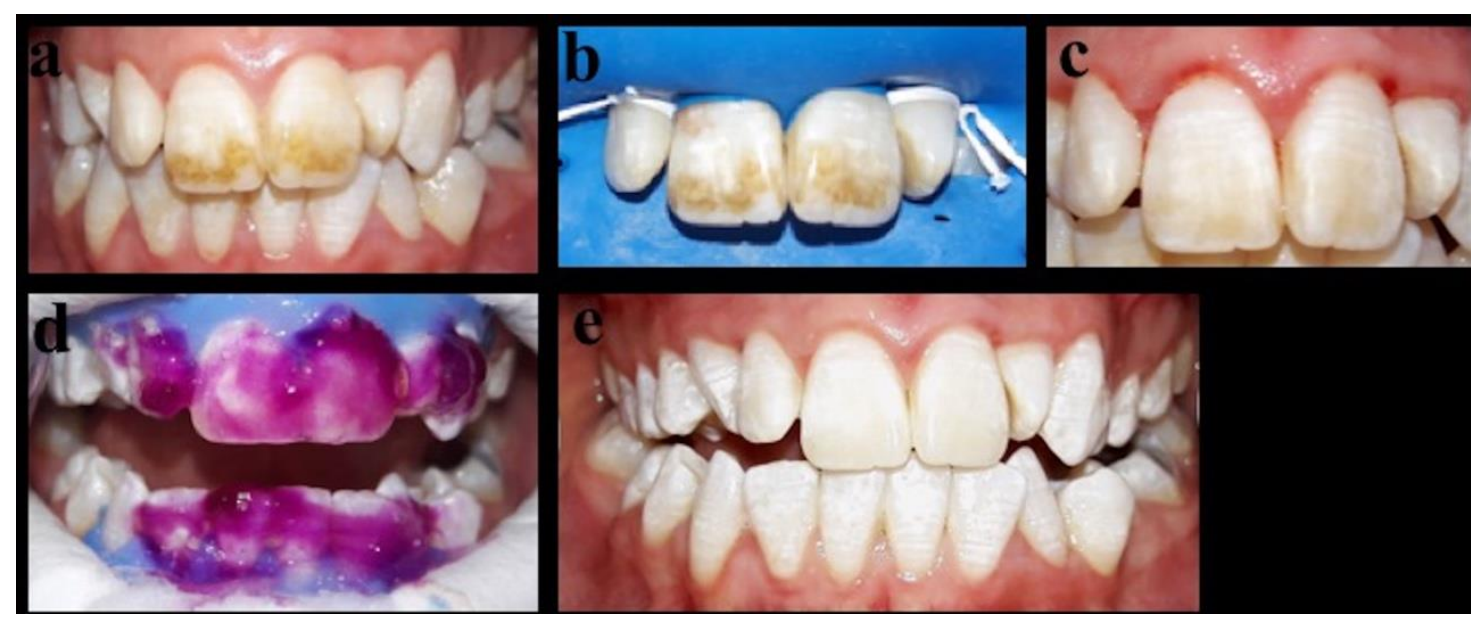

Resim 10: Florozisli dişlerin estetik rehabilitasyonu: a. Üst ve alt çenenin başlangıç klinik görünümü, b. Üst çene santral dişlerdeki kahverengi renkleşmeler, c. Renkleşmelerin mikroabrazyon uygulaması ile giderilmesi (Opalustre abrazyon patı, Ultradent Products, USA), d. Ofis tipi beyazlatma materyalinin 2 seans uygulanması (Whiteness HP Maxx, FGM Produtos, Joinville, SC, Brazil), e. 1 hafta sonraki ağız içi görünümü.

BAKH'li hastalarda tedavi prosedürlerine yaşa ve kusurların şiddetine ve etkilenen diş grubunun cinsine göre karar verilmektedir. Sürme sonrası yıkıma uğramamış semptomsuz büyük azı dişlerinde hassasiyetin ve çürüklerin önlenmesi için topikal florür uygulaması, düşük viskositeli cam iyonomer fissür örtücü ve CCP-ACP gibi remineralizasyon uygulamaları önerilmektedir (Aldred et al., 2013). Ön grup dişlerde renkleşmeler mikroabrazyon ve beyazlatma uygulamaları ile giderilebilmekte, opak lezyonlar ise reçine infiltrasyon yöntemiyle onarılabilmektedir (Patel et al., 2019). Orta şiddetli lezyonlar cam iyonomer veya kompozit restorasyonlar ile tedavi edilebilmektedir. (Resim-11,12).

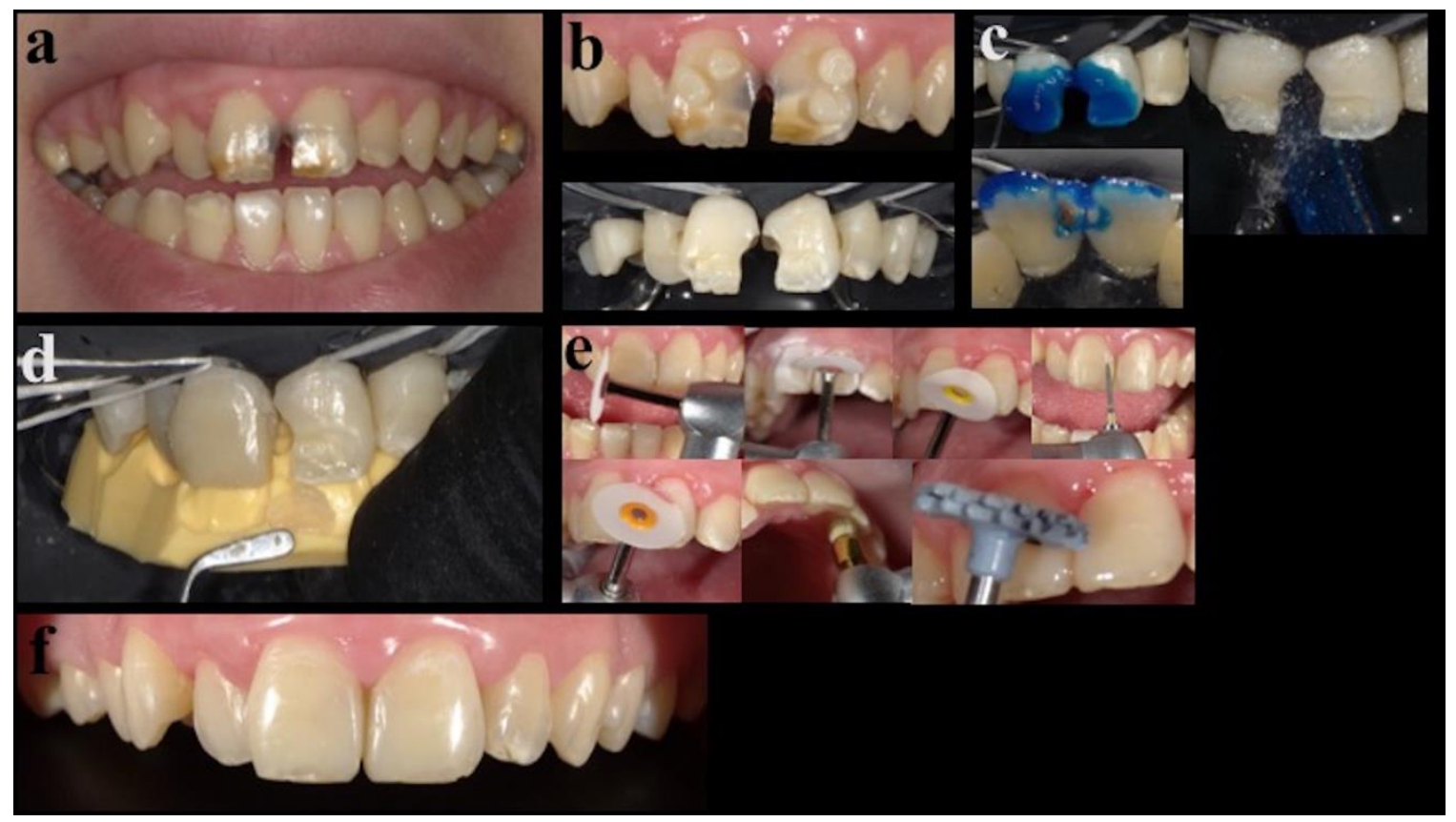

Resim 11: BAKH'li dişlerin direkt kompozit reçine restorasyonlarla rehabilitasyonu: a. Başlangıç

klinik görünümü, ön bölge kesici ve üst birinci büyük azı dişlerde hipomineralizasyon lezyonları, b.

Kompozit butonları ile renk tayini, rubber-dam izolasyonu sonrası mine defektleri ve çürük lezyonların uzaklaştırılması, c. Minenin selektif olarak asit ile pürüzlendirilmesi, d. Silikon rehber ile palatinal mine duvarı oluşturulması, e. Restorasyonun tamamlanması sonrası bitim-cila prosedürlerinin uygulanması, f. Restorasyonların bitim sonrası görünümü. 


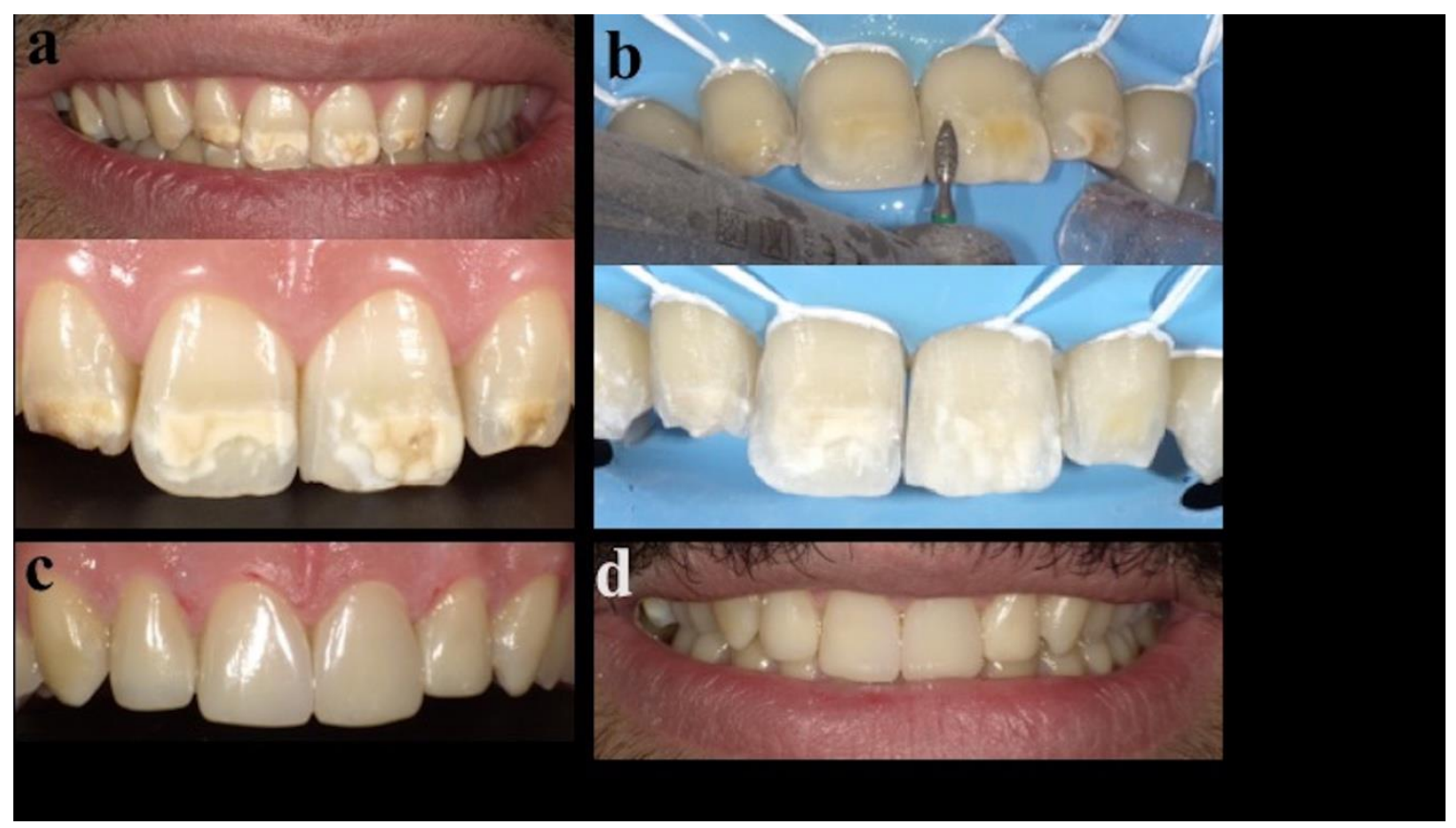

Resim 12: BAKH'li dişlerin direkt kompozit reçine restorasyonlarla rehabilitasyonu: a.

Lezyonların klinik görünümü, b. Renk seçimi yapıldıktan sonra rubber-dam izolasyonu sağlandı. Minedeki opak lezyonlar elmas labut frezle uzaklaştırıldı. Mine yüzeyleri 15 sn \%35'lik ortofosforik asit (Scotchbond Universal Etchant, 3M ESPE, St Paul, MN, USA) ile pürüzlendirildi, universal dentin adezivi (Scotchbond Universal, 3M ESPE, St Paul, MN, USA) üretici firma önerileri doğrultusunda

uyguland1. Restorasyonlar A2-Dentin/A2-Mine renkli nanohibrit reçine kompozit (Harmonize Nanohybrid Universal Composite Kerr Corporation, Orange, CA) ile tamamlandı. Restorasyonların bitim ve cila işlemleri sırasıyla, kırmızı ve sarı bantlı cila frezleri, alüminyum oksit kaplı cila diskleri (Super-Snap Rainbow-Technique-Kit, Shofu, Kyoto, Japan) ve elmas emdirilmiș cila spiralleri (Clearfil Twist Dia, Kuraray Europe Gmbh, Hattersheim am Main, Germany) ile gerçekleștirildi, c. Restorasyon bitimi sonrası görünümü, d. 18 aylık ağız-dışı görüntüsü, tüm restorasyonlu dişler FDI kriterlerine göre

Skor 1 olarak değerlendirilmiştir.

BAKH'lı minenin asit ile pürüzlenme paterni ve dolayısıyla bağlantı kuvvetleri sağlıklı mineye göre farklıdır. Bunun nedeni prizmaların sınırlarındaki deviasyonlar ve defektli kısımların asit ile uniform bir şekilde uzaklaştırılamamasıdır. $\mathrm{Bu}$ nedenle adeziv restorasyonlar uygulanacaksa bağlantının artırılması için \%5'lik sodyum hipoklorit uygulaması ile protein denatürasyonu gibi ilave prosedürlere ihtiyaç vardır (Schuurs, 2013; Elhennawy et al., 2017; Ekambaram \& Yiu, 2016; Aldred et al., 2013). Tüberküllerin etkilendiği geniş defektli birinci büyük azılarda mine kırığa dirençli bir restorasyon (tercihen fiber destekli kompozit veya indirekt restorasyonlar) ile desteklenmelidir (Elhennawy et al., 2017). Çocuk hastalarda çok hasarlı dişlerde paslanmaz çelik kuronlar veya azıların çekimi sonrası boşluğun spontan kapanması veya ortodontik tedaviler önerilmektedir (Yamaguti \& Cabral, 2019).

Amelogenesis imperfektanın tipleri restorasyon tipini ve ömrünü belirlemektedir. İleri derece mine dokusu kaybına uğramamış veya özellikle çukurcuklu hipoplastik tipteki lezyonlar direkt veya indirekt adeziv restorasyonlar ile başarıyla tedavi edilebilmektedir (Resim-13), ancak dikey boyut kaybı olan ileri dereceli vakalarda ise öncelikle okluzyonun düzenlenmesi gerekmektedir (Ekambaram \& Yiu, 2016). 


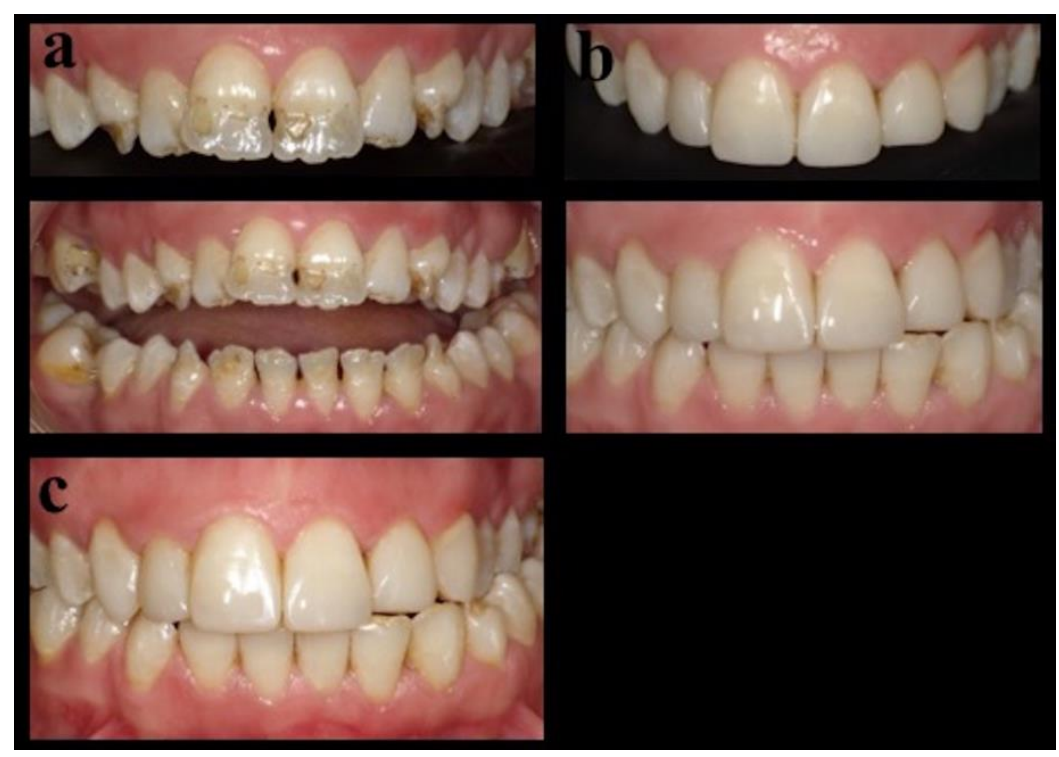

Resim 13. Hipoplastik tip amelogenesis imperfektalı dişlerin direkt kompozit reçine

restorasyonlarla rehabilitasyonu: a. Üst ve alt çenenin başlangıç klinik görünümü. Üst ve alt çene ön bölge dişlerinin bukkal yüzeylerinin direkt kompozit vener restorasyon ile estetik rehabilitasyonu için

15 sn \%35'lik ortofosforik asit (Scotchbond Universal Etchant, 3M ESPE, St Paul, MN, USA) ile pürüzlendirilen mine yüzeylerine self-etch adeziv sistem (Clearfil SE bond, Kuraray, Tokyo, Japan)

uygulandı. Bukkal yüzeylerin kole bölgesi A2 Body, orta ve insizal 1/3 bölgesi A1 Body renkli nanohibrit kompozit (Clearfil Majesty ES-2 Classic, Kuraray, Tokyo, Japan) ile restore edildi. b. Bitim sonrası ağız içi görüntüsü, c. 6 aylık kontrol ağız içi görüntüsü.

Hipomatür ve hipomineralize lezyonlarda mine kalitesiz, yumuşak ve yüksek oranda protein içerdiğinden adeziv restorasyonlarda bağlantı problemleri yaşanabilmektedir. Çalı̧̧malarda adeziv restorasyonlar uygulanacağı taktirde defektli minenin uzaklaştırılması ve asitle pürüzlendirme sonrası hipomineralize dişin sodyum hipoklorit ile deproteinize edilmesi gerektiği belirtilmektedir (Yamaguti \& Cabral, 2019; Ekambaram \& Yiu, 2016).

Mine dokusunun tamamen ortadan kalktığı, peynirimsi yumuşaklıktaki hipomatür veya hipomineralize tipteki ileri derecede estetik ve fonksiyon kaybına uğramış dişlerde adeziv restorasyonlar endike değildir, indirekt protetik restorasyonlar tercih edilebilmektedir (Yamaguti \& Cabral, 2019). Bir çalışmada hipersensitivite, estetik ve çiğneme şikayetleri olan 16 yaşındaki erkek hastanın klinik muayenesinde hassasiyet nedenli kötü oral hijyene bağlı olarak tüm dişlerinde yüksek miktarda plak birikimi ve generalize pürüzlü, sarı-kahverengi mine kusurları ve mine kaybına bağlı açığa çıkmış dentin dokusu gözlenmiștir. 3mm'lik ön açck kapanıșı, okluzal yüzeylerde harabiyete bağlı olarak kısalmış azı dişleri olan ancak okluzal dikey boyut kaybı söz konusu olmayan hastanın sefalometrik analizinde iskeletsel sınıf III anomaliye sahip olduğu, radyografik muayenesinde trabeküler yapısının normal olduğu, alt ve üst çenede daimî kanin ve üçüncü büyük azı dişlerinin gömük olduğu tespit edilmiştir. Dental hikayesinde 11 yaşındayken dental tedavilerinin aşırı dentin hassasiyetinin yaratmış olduğu dental anksiyete nedeniyle sedasyon altında yapıldığı öğrenilen hastaya hipomatür tip amelogenesis imperfekta tanısı konulmuştur. Hastanın tedavi planlamasında, ağız hijyeninin iyileştirilmesi sonrası hipersensitivitenin ortadan kaldırılması ve estetik, fonetik ile çiğneme fonksiyonlarının optimize edilebilmesi için tüm diş yüzeylerinin protetik restorasyonlarla örtülenmesi gerektiğine karar verilmiştir. Hastanın büyüme ve gelişimi devam ettiği için, 2 ayda bir yenilenmek üzere, uzun dönemli geçici CAD/CAM kompozit polimetil metakrilat (PMMA) kuron restorasyonları uygulanmıştır. Hasta 18 yaşına ulaştığında daimî protetik tedavileri, seramik kuronlar adeziv kompozit siman (Multilink, Ivoclar Vivadent) ile metal-seramik kuronlar cam iyonomer siman (Fuji, GC America) ile simante edilerek tamamlanmışıtır (Ortiz et al., 2019).

Adeziv sistemlerdeki gelişmeler reçine kompozit restorasyonların gelişimsel mine kusurlarının tedavisinde başarı ile uygulanmasına olanak vermektedir. Ancak mine yapısınının normalden farklı olması nedeniyle bağlantı problemleri oluşmakta ve bu bağlantıyı artırıcı yöntemler ile ilgili daha çok klinik veya in-vitro çalışmaya ihtiyaç duyulmaktadır. Chay ve arkadaşları hipomineralize mine 
dokusunun bağlanma dayanımını artırmaya yönelik yaptıkları bir çalışmada lezyonun kısmi olarak uzaklaştırılması ve asit uygulaması sonrası \%5,25'lik $\mathrm{NaOCl}^{\prime}$ in $1 \mathrm{dk}$ bekletilmesi ile reçinenin penetrasyonunun artırılabileceğini belirtmişlerdir (Chay et al., 2014). Kramer ve arkadaşları BAKH'den etkilenmiş mine ve dentindeki farklı bağlanma stratejilerinin araştırıldığı çalışmada $\mathrm{NaOCl}$ veya Icon uygulamalarının bağlantıyı artırmadığını, iki aşamalı etch and rinse ve iki aşamalı self-etch sistemin 3 basamaklı etch and rinse sisteme göre daha kötü bağlanma dayanımı sergilediğini bildirmişlerdir. Fosforik asit ile pürüzlendirme işlemi sonrası yapılan mikromorfolojik analizler, yetersiz porözite ve normalden farklı bir pürüzlenme paterni oluştuduğunu göstermektedir (Kramer., 2018).

\section{Sonuç}

Gelişimsel mine kusurlarının yaygınlığı dünya genelince \%10 ile \%80 arasında değişmektedir (Wright, 2018). Defektli mine yapısal olarak zayıf olduğundan, çiğneme stresleri altında kolayca hasara uğrar, bu durum restorasyonlar ile doku arasında marjinal sızıntı, sekonder çürük ve hatta hasarın pulpa enfeksiyonuna kadar ilerlemesine neden olabilmektedir. Bu kusurlara sahip hastalarda hassasiyet, aşınma, morfolojik farklılıklar, yaygın çürükler, renkleşmeler, kötü estetik, fonksiyon kısıtlanması gibi şikayetler söz konusudur. Bu kusurların giderilmesi hastaların psiko-sosyal açıdan da iyileştirilmesini sağlamakta ve hayat kalitelerindeki olumsuz etkiyi ortadan kaldırmaktadır. Adeziv restorasyonlar minimal invaziv yaklaşımla uygulanabilirlik, tek seansta ve kısa sürede uygulanabilirlik, düşük maliyet, tamir edilebilme özellikleri sayesinde bu kusurların tedavisinde daha çok tercih edilmekte ve başarı ile uygulanabilmektedir.

\section{Referanslar}

Aldred MJ, Cameron AC, King NM, Widmer RP. (2013). Dental anomalies. Handbook of Pediatric Dentistry. 269-328.

Ansari G, Golpayegani MV, Welbury R. (2018). Atlas of Pediatric Oral and Dental Developmental Anomalies. Wiley-Blackwell, West Sussex, UK. 21-61.

Aytug AF, Gürbüz O, Ergun T, Kotiloğlu E. (2002). Endojen okronozis: Bir alkaptonüri olgusu. Türkderm. 36: 276-279.

Bağbozan G. (1995). Gebelikte rh ve ab0 kan grup uyuşmazlıkları. İstanbul tıp dergisi. 3: 38-42.

Barzotto I, Rigo L. (2018). Clinical decision making for diagnosis and treatment of dental enamel injuries. J Hum Growth Dev. 28(2):189-198.

Barzotto I, Rigo L. (2018). Clinical decision making for diagnosis and treatment of dental enamel injuries. J Hum Growth Dev. 28(2):189-198.

Bayar ÖF, Ak G. (2016). Squamous hücreli karsinom gelişen Epidermolizis Bülloza ve dental tedavi yaklaşımları. Ata Diş Hek Fak Derg. 25(13): 0-0.

Beniash E, Stifler CA, Sun CY, et al. (2019). The hidden structure of human enamel. Nat Commun. 10(1):4383.

Berke N, Keklikoğlu N. (2010). Nöral krest kökenli hücrelerin ağız ve çene yüz oluşumuna katkılar1. İÜDHF. 44(1): 39-43.

Bilgin EŞ, Pınar Erdem A. (2016). Gelişimsel mine defektleri ve tedavi yaklaşımları. Ata Diş Hek Fak Derg. 26; 334-343.

Chatzopoulos G, Tziafas D. (2014). Molecular basis of human enamel defects. Balkan Journal of Dental Medicine. 18(1): 5-16. 
Chay PL, Manton DJ, Palamara JE. (2014). The effect of resin infiltration and oxidative pretreatment on microshear bond strength of resin composite to hypomineralised enamel. Int $\mathrm{J}$ Paediatr Dent. 24(4):252-267.

Chiego DJ. (2018). Essentials of oral histology and embryology: a clinical approach. 5th Ed., Elsevier Inc., St. Louis, Missouri. 1-17.

Chiego DJ. (2018). Essentials of oral histology and embryology: a clinical approach. 5th Ed., Elsevier Inc., St. Louis, Missouri. 59-74.

Chosack A, Eidelman E, Wisotski I, Cohen T. (1979). Amelogenesis imperfecta among Israeli Jews and the description of a new type of local hypoplastic autosomal recessive amelogenesis imperfecta. Oral Surg. Oral Med. Oral Path. 47: 148-156.

Cochran JA, Ketley CE, Sanches L et al. (2004). A standardized photographic method for evaluating enamel opacities including fluorosis. Community Dentistry and Oral Epidemiology. 32(1), 19-27.)

Crawford PJ, Aldred M, Bloch-Zupan A. (2007). Amelogenesis imperfecta. Orphanet J Rare Dis. $4(2): 17$.

Dedekayaoğulları H, Önal AE. (2009). Çevre-insan sağlığı ilişkisi açısından su ve su analizinin önemi. İst tıp fak derg. 72: 65-70.

Deutsch D, Palmon A. Young M F et al. (1994). Mapping of the human tuftelin (TUFT1) gene to chromosome 1 by fluorescence in situ hybridization. Mammalian Genome. 5: 461-462.

Di Giovanni T, Eliades T, Papageorgiou SN. (2018). Interventions for dental fluorosis: A systematic review. J Esthet Restor Dent. 30(6):502-508.

Ekambaram M, Yiu CKY. (2016). Bonding to hypomineralized enamel - A systematic review. International Journal of Adhesion and Adhesives. 69: 27-32.

Elfrink MEC, Schuller AA, Weerheijm KL, Veerkamp JSJ. (2008). Hypomineralized second primary molars: prevalence data in Dutch 5-year-olds. Caries Research. 42(4), 282-285.

Elhennawy K, Manton DJ, Crombie F et al. (2017). Structural, mechanical and chemical evaluation of molar-incisor hypomineralization-affected enamel: A systematic review. Archives of Oral Biology. 83: 272-281.

Garot E, Denis A, Delbos Y, Manton D, Silva M, Rouas P. (2018). Are hypomineralised lesions on second primary molars (HSPM) a predictive sign of molar incisor hypomineralisation (MIH)? A systematic review and a meta-analysis. Journal of Dentistry. 72: 8-13.

Görmüş U. (2011). The relationship of embryogenesis and carcinogenesis. Nobel Med. 7(3): 05-09.

Hatun Ş, Bereket A, Çalıkoğlu AS, Özkan B. (2003). Günümüzde d vitamini yetersizliği ve nütrisyonel rikets. Çocuk sağlı̆̆1 ve hastalıkları dergisi. 46: 224-241.

Hazar Bodrumlu E, Avşar A. (2015). Büyük azı ve kesici diş hipomineralizasyonu: etiyolojisi ve kliniği. Acta Odontol Turc. 32(2):90-7.

Hu JC, Chun YH, Al Hazzazzi T, Simmer JP. (2007). Enamel formation and amelogenesis imperfecta. Cells, tissues, organs. 186(1):78-85.

Kammoun R, Zmantar T, Labidi A, Abbes I, Mansour L, Ghoul-Mazgar S. (2019). Dental caries and hypoplastic amelogenesis imperfecta: Clinical, structural, biochemical and molecular approaches. Microbial Pathogenesis. 135: 103615. 
Kaste SC, Goodman P, LeisenringW, et al. (2009). Impact of radiation and chemotherapy on risk of dental abnormalities: a report from the Childhood Cancer Survivor Study. Cancer. 115:58175827.

Kaste SC, Hopkins KP, Jenkins JJ. (1994). Abnormal odontogenesis in children treated with radiation and chemotherapy: imaging findings. AJR Am J Roentgenol. 162: 1407-1411.

Kim JW, Simmer JP, Hart TC et al. (2005). MMP-20 mutation in autosomal recessive pigmented hypomaturation amelogenesis imperfecta. J. Med. Genet. 42: 271-275.

Kim JW, Zhang H, Seymen F et al. (2019). Mutations in RELT cause autosomal recessive amelogenesis imperfecta. Clin. Genet. 95: 375-383.

Koruyucu M, Özel S, Tuna EB. (2018). Prevalence and etiology of molar-incisor hypomineralization (MIH) in the city of Istanbul. J Dent Sci. 13(4):318-328.

Krämer N, Bui Khac NN, Lücker S, Stachniss V, Frankenberger R. (2018). Bonding strategies for MIH-affected enamel and dentin. Dent Mater. 34(2):331-340.

Kwon HJE, Jiang, R. (2018). Development of teeth. Reference module in biomedical sciences. Elsevier.

Matalová E, Lungová V, Sharpe P. (2015). Development of tooth and associated structures. Stem Cell Biology and Tissue Engineering in Dental Sciences. 335-346.

Mendoza G, Pemberton TJ, Lee K et al. (2007). A new locus for autosomal dominant amelogenesis imperfecta on chromosome 8q24.3. Hum. Genet. 120: 653-662.

Moore KL, Persaud TV, Torchia MG. (2016). The developing human: clinically oriented embryology. 10 th Ed., Elsevier Health Sciences, Philadelphia, PA. 1-10.

Moore KL, Persaud TV, Torchia MG. (2016). The developing human: clinically oriented embryology. 10 th Ed., Elsevier Health Sciences, Philadelphia, US. 437-457.

Moore LM, Persaud TVN. (2016). The Developing Human: Clinically Oriented Embryology. 10th ed., Saunders, Philadelphia, PA. 19: 437-457.

Muñoz MA, Arana-Gordillo LA, Gomes GM, et al. (2013). Alternative esthetic management of fluorosis and hypoplasia stains: blending effect obtained with resin infiltration techniques. J Esthet Restor Dent. 25(1):32-39.

Nanci A. (2018). Ten Cate's oral histology. 9th Ed., Elsevier Health Sciences, St. Louis, Missouri. $18-45$.

Nanci A. (2018). Ten Cate's oral histology. 9th Ed., Elsevier Health Sciences, St. Louis, Missouri. 289-369.

Nanci A. (2018). Ten Cate's oral histology. 9th Ed., Elsevier Health Sciences, St. Louis, Missouri. 46-69.

Neville D, Damm D, Allen D et al. (2015). Oral and maxillofacial pathology. 3rd Ed., Elsevier Health Sciences, St. Louis, Missouri. 54-119.

Nowak A, Christensen JR, Mabry TR, Townsend JA, Wells MH. (2019). Pediatric dentistry- infancy through adolescence. 6th Ed., Elsevier Health Sciences, Philadelphia, PA. 258-409.

Ortiz L, Pereira AM, Jahangiri L, Choi M. (2019). Management of amelogenesis imperfecta in adolescent patients: clinical report. J Prosthodont. 28(6):607-612. 
Owosho AA, Brady P, Wolden SL et al. (2016). Long-term effect of chemotherapy-intensitymodulated radiation therapy (chemo-IMRT) on dentofacial development in head and neck rhabdomyosarcoma patients. Pediatric Hematology and Oncology. 33(6): 383-392.

Paris S, Meyer-Lueckel H. (2009). Masking of labial enamel white spot lesions by resin infiltration-a clinical report, Quintessence Int. 40(9); 713-718.

Parry DA, Brookes SJ, Logan CV et al. (2012). Mutations in C4orf26, encoding a peptide with in vitro hydroxyapatite crystal nucleation and growth activity, cause amelogenesis imperfecta. Am. J. Hum. Genet. 91: 565-571.

Patel A, Aghababaie S, Parekh S. (2019). Hypomineralisation or hypoplasia? Br Dent J. ;227(8):683-686.

Poulter JA, Murillo G, Brookes SJ et al. (2014). Deletion of ameloblastin exon 6 is associated with amelogenesis imperfecta. Hum. Molec. Genet. 23: 5317-5324.

Schoppmeier CM, Derman SHM, Noack MJ, Wicht MJ. (2018). Power bleaching enhances resin infiltration masking effect of dental fluorosis. A randomized clinical trial. Journal of Dentistry. 79: 77-84.

Schuurs A. (2013). Pathology of the hard dental tissues. Wiley-Blackwell, West Sussex, UK. 50-95.

Schwendicke F, Elhennawy K, Reda S, Bekes K, Manton DJ, Krois J. (2018). Global burden of molar incisor hypomineralization. Journal of Dentistry. 68: 10-18.

Seow W. (2014). Developmental defects of enamel and dentine: challenges for basic science research and clinical management. Aust Dent J. 59: 143-154.

Seow WK. (1997). Clinical diagnosis of enamel defects: Pitfalls and practical guidelines. International Dental Journal. 47(3): 173-182.

Sevinç N, Türkmen M, Soylu A, Kavukçu S. (2005). X’e bağlı hipofosfatemik rikets. Çocuk sağlı̆̆ı ve hastalıkları dergisi. 48:49-53.

Smeets PJ, DeRocher K, Zachman MJ, Goodge BH, Kourkoutis LF, Joester D. (2019). Atomicscale characterization reveals core-shell structure of enamel crystallites. Microsc Microanal. 25(S2): 1722-1723.

Smith CEL, Murillo G, Brookes SJ et al. (2016). Deletion of amelotin exons 3-6 is associated with amelogenesis imperfecta. Hum. Molec. Genet. 25: 3578-3587.

Söylemez-Gökyer D, Kayaaltı Z. (2016). Türkiye'de orak hücreli anemi dağılımı, patofizyolojisi ve demir toksisitesi. Marmara pharmaceutical journal. 20:92-99.

Turgut CT, Palancıoğlu A, Yaltırık M. (2018). Vitamin D and it's importance in oral healt. Türkiye Klinikleri Journal of Dental Sciences. 24(3): 239-247.

Wang SK, Aref P, Hu Y et al. (2013). FAM20A mutations can cause enamel-renal syndrome (ERS). PLoS Genet. 9: e1003302.

Weerheijm KL, Jälevik B, Alaluusua S. (2001). Molar-incisor hypomineralisation. Caries research. 35(5): 390-391.

Weerheijm KL. (2004). Molar incisor hypomineralization (MIH): clinical presentation, aetiology and management. Dent Update. 31(1):9-12. 
Willmott NS, Bryan RAE, Duggal MS. (2008). Molar-incisor- hypomineralisation: a literatüre review. Eur Arch Paediatr Dent. 9: 172-179.

Witkop CJ, Sauk JJ. (1976). Heritable defects of enamel. Stewart RE, Prescott GH. Oral Facial Genetics. St. Louis, C. V. Mosby. 187.

Witkop CJ. (1988). Amelogenesis imperfecta, dentinogenesis imperfecta and dentin dysplasia revisited: problems in classification. Journal of Oral Pathology and Medicine. 17(9-10): 547553.

Wright JT, Carrion IA, Morris C. (2015). The molecular basis of hereditary enamel defects in humans. J Dent Res. 94(1):52-61.

Wright JT, Torain M, Long K et al. (2011). Amelogenesis imperfecta: genotype-phenotype studies in 71 families. Cells Tissues Organs. 194(2-4):279-83.

Wright JT. (2018). Developmental defects of enamel. Reference Module in Biomedical Sciences. Elsevier.

Yamaguti PM, Cabral RN. (2015). Developmental defects of enamel. Leal SC, Takeshita EM. Pediatric restorative dentistry. Springer Nature, Cham, Switzerland, 2019, 93-116.

Zhang H, Hu Y, Seymen F, et al. (2019). ENAM mutations and digenic inheritance. Mol Genet Genomic Med. 7(10): 00928. 